\title{
Recent Tropical Expansion: Natural Variability or Forced Response? 0
}

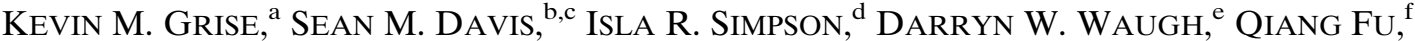 \\ Robert J. Allen, ${ }^{\mathrm{g}}$ KAREN H. Rosenlof,${ }^{\mathrm{b}}$ CAROLIne C. UMMENHOFer, ${ }^{\mathrm{h}}$ \\ KRISTOPHER B. KARNAUSKAS, ${ }^{\mathrm{c}, \mathrm{i}}$ AMANDA C. MAYCOCK, ${ }^{\mathrm{j}}$ XIAO-Wei QuAN, ${ }^{\mathrm{b}, \mathrm{c}}$ \\ THOMAS BIRNER, ${ }^{k}$ AND PAUl W. STATEN ${ }^{1}$ \\ a Department of Environmental Sciences, University of Virginia, Charlottesville, Virginia \\ ${ }^{\mathrm{b}}$ NOAA/Earth System Research Laboratory, Boulder, Colorado \\ ${ }^{c}$ Cooperative Institute for Research in Environmental Sciences, University of Colorado Boulder, Boulder, Colorado \\ ${ }^{\mathrm{d}}$ Climate and Global Dynamics Laboratory, National Center for Atmospheric Research, Boulder, Colorado \\ ${ }^{\mathrm{e}}$ Department of Earth and Planetary Sciences, The Johns Hopkins University, Baltimore, Maryland \\ ${ }^{\mathrm{f}}$ Department of Atmospheric Sciences, University of Washington, Seattle, Washington \\ ${ }^{\mathrm{g}}$ Department of Earth Sciences, University of California, Riverside, Riverside, California

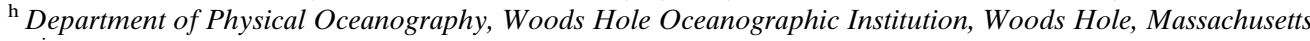 \\ ${ }^{\mathrm{i}}$ Department of Atmospheric and Oceanic Sciences, University of Colorado Boulder, Boulder, Colorado \\ ${ }^{\mathrm{j}}$ School of Earth and Environment, University of Leeds, Leeds, United Kingdom \\ ${ }^{\mathrm{k}}$ Ludwig-Maximilians-University, Munich, Germany \\ ${ }^{1}$ Department of Earth and Atmospheric Sciences, Indiana University Bloomington, Bloomington, Indiana
}

(Manuscript received 9 July 2018, in final form 8 December 2018)

\begin{abstract}
Previous studies have documented a poleward shift in the subsiding branches of Earth's Hadley circulation since 1979 but have disagreed on the causes of these observed changes and the ability of global climate models to capture them. This synthesis paper reexamines a number of contradictory claims in the past literature and finds that the tropical expansion indicated by modern reanalyses is within the bounds of models' historical simulations for the period 1979-2005. Earlier conclusions that models were underestimating the observed trends relied on defining the Hadley circulation using the mass streamfunction from older reanalyses. The recent observed tropical expansion has similar magnitudes in the annual mean in the Northern Hemisphere $(\mathrm{NH})$ and Southern Hemisphere (SH), but models suggest that the factors driving the expansion differ between the hemispheres. In the $\mathrm{SH}$, increasing greenhouse gases (GHGs) and stratospheric ozone depletion contributed to tropical expansion over the late twentieth century, and if GHGs continue increasing, the SH tropical edge is projected to shift further poleward over the twenty-first century, even as stratospheric ozone concentrations recover. In the $\mathrm{NH}$, the contribution of GHGs to tropical expansion is much smaller and will remain difficult to detect in a background of large natural variability, even by the end of the twenty-first century. To explain similar recent tropical expansion rates in the two hemispheres, natural variability must be taken into account. Recent coupled atmosphere-ocean variability, including the Pacific decadal oscillation, has contributed to tropical expansion. However, in models forced with observed sea surface temperatures, tropical expansion rates still vary widely because of internal atmospheric variability.
\end{abstract}

\section{Introduction}

Earth's tropical belt is characterized by regions of intense rainfall near the equator and arid zones in the subtropics of each hemisphere. Together, these moist and dry

Supplemental information related to this paper is available at the Journals Online website: https://doi.org/10.1175/JCLID-18-0444.s1.

Corresponding author: Kevin M. Grise, kmg3r@virginia.edu regions of the tropics are surface manifestations of the Hadley circulation, with rising motion in tropical deep convective regions and subsidence in the subtropics. A growing body of evidence has suggested that the Hadley circulation has widened in recent decades, pushing its subsiding branches and the attendant subtropical dry zones further poleward (Seidel et al. 2008; Davis and Rosenlof 2012; Birner et al. 2014; Lucas et al. 2014; Staten et al. 2018). As a result, many recent studies have sought to accurately quantify the trend in the width of the Hadley circulation and identify its underlying causes. 
A decade ago, a number of studies documented a wide range of estimates of tropical widening $\left(0.25^{\circ}-3^{\circ}\right.$ latitude decade ${ }^{-1}$ ) over the period from 1979 until 2001-05 based on satellite, radiosonde, and reanalysis data (Fu et al. 2006; Hudson et al. 2006; Hu and Fu 2007; Seidel and Randel 2007; Archer and Caldeira 2008; Seidel et al. 2008; Johanson and Fu 2009, hereafter JF09). Some of these studies concluded that the observed rates of widening were substantially larger than those simulated in global climate models driven by anthropogenic forcing, which have a multimodel mean trend of $0.1^{\circ}-0.3^{\circ}$ latitude decade ${ }^{-1}$ (JF09; Hu et al. 2013). At the time, it was suggested that models might be underestimating the sensitivity of the atmospheric circulation to anthropogenic forcing.

In the 10 years since, a qualitative shift has occurred in the literature. A number of studies are now finding more modest rates of observed tropical expansion $\left(0.2^{\circ}-0.6^{\circ}\right.$ latitude decade ${ }^{-1}$ ) over the period from 1979 until 2005-09 based on updated satellite, reanalysis, and surface observational datasets (Fu and Lin 2011; Allen et al. 2014, hereafter A14; Davis and Birner 2017; Davis and Davis 2018; Grise et al. 2018; Staten et al. 2018). Consequently, many studies are now concluding that the observed trends do not exceed those in global climate model simulations (Adam et al. 2014; Garfinkel et al. 2015; Davis and Birner 2017; Grise et al. 2018). Additionally, many studies are now suggesting that a large fraction of the recent tropical expansion can be attributed to natural climate variability instead of anthropogenic forcing (A14; Garfinkel et al. 2015; Allen and Kovilakam 2017; Mantsis et al. 2017; Amaya et al. 2018). In light of this substantial change in viewpoint, this paper reflects the efforts of the U.S. Climate Variability and Predictability Program (CLIVAR) Working Group on the Changing Width of the Tropical Belt to reassess contradictory claims in the literature about the magnitude and causes of the recent tropical widening and to synthesize key conclusions on the topic.

There is good reason to suspect that anthropogenic forcing played a role in the recent expansion of the tropics. Hadley cell widening is a robust response of global climate models forced with increasing greenhouse gases (GHGs; $\mathrm{Lu}$ et al. 2007; $\mathrm{Hu}$ et al. 2013; Quan et al. 2014; Grise and Polvani 2016; Tao et al. 2016), and atmospheric $\mathrm{CO}_{2}$ concentrations have increased by $\sim 50 \mathrm{ppm}$ from 1979 to 2008 and $\sim 70 \mathrm{ppm}$ from 1979 to present day (Keeling et al. 2001; Tans 2018). The mechanism behind GHG-forced tropical expansion is still subject to debate (see Staten et al. 2018) but likely reflects how baroclinic eddies respond to changes in static stability (Frierson et al. 2007; Korty and Schneider 2008; Lu et al. 2010; Vallis et al. 2015) and horizontal temperature gradients (Brayshaw et al. 2008; Butler et al. 2011) in the subtropical and extratropical atmosphere in a warming climate. The direct radiative effects of increasing GHGs, independent of warming sea surface temperatures (SSTs), also contribute to a small poleward expansion of the tropics (He and Soden 2015, 2017). Overall, model simulations driven by GHG forcing (direct radiative effects + warming SSTs) show that the poleward expansion of the Hadley circulation is particularly pronounced during fall in the Northern Hemisphere $(\mathrm{NH})$ and summer and fall in the Southern Hemisphere $(\mathrm{SH} ; \mathrm{Hu}$ et al. 2013; Davis et al. 2016; Grise and Polvani 2016; Tao et al. 2016). While models generally agree that the poleward edges of the Hadley cell shift poleward in response to increasing GHGs, the magnitude of the poleward expansion varies greatly among models, reflecting intermodel differences in cloud feedbacks (Voigt and Shaw 2015; Ceppi and Hartmann 2016; Tandon and Cane 2017) among other factors.

In the $\mathrm{SH}$, stratospheric ozone depletion likely played a major role in the recent observed tropical expansion. Over the last two decades of the twentieth century, stratospheric ozone concentrations over Antarctica declined dramatically during spring months, cooling the SH polar stratosphere and strengthening the stratospheric polar vortex (e.g., Randel and Wu 1999; Waugh et al. 1999). Both observational and modeling studies have shown that these stratospheric circulation changes descend to tropospheric levels during summer months (DJF), resulting in a poleward shift of the SH midlatitude eddy-driven jet stream (Thompson and Solomon 2002; Gillett and Thompson 2003; Thompson et al. 2011) and Hadley cell edge (Lu et al. 2009; Son et al. 2010; McLandress et al. 2011; Polvani et al. 2011a; Staten et al. 2012; Min and Son 2013). Many of these studies have concluded that the influence of stratospheric ozone depletion on the $\mathrm{SH}$ tropospheric circulation greatly exceeded that of increasing GHGs during the DJF season from 1960 until the end of the twentieth century (McLandress et al. 2011; Polvani et al. 2011a; Min and Son 2013; Garfinkel et al. 2015; Waugh et al. 2015). Atmospheric concentrations of ozone-depleting substances peaked around the year 2000 (e.g., Carpenter et al. 2014), and there is emerging observational evidence that the Antarctic ozone hole is beginning to heal (S. Solomon et al. 2016, 2017). Consequently, the tropical expansion associated with stratospheric ozone depletion has likely already maximized and is expected to reverse over the twenty-first century as the ozone hole recovers (Son et al. 2009; McLandress et al. 2011; Polvani et al. 2011b).

In the $\mathrm{NH}$, tropospheric air pollutants (anthropogenic aerosols and tropospheric ozone) may have played a 
role in the recent observed tropical expansion. Experiments in idealized and comprehensive global climate models show that heating in the midlatitude lower troposphere (where tropospheric air pollution is largest in the $\mathrm{NH}$ ) produces large poleward shifts in the Hadley cell edge (Allen et al. 2012a; Tandon et al. 2013). As a result, black/brown carbon aerosols and ozone at tropospheric levels, which warm the troposphere, have been hypothesized to contribute to a poleward shift in the NH Hadley cell edge over the twentieth century (Allen and Sherwood 2011; Allen et al. 2012b; Kovilakam and Mahajan 2015). Black carbon aerosols in the upper troposphere, although less abundant, have been suggested to be particularly effective at driving tropical expansion (Shen and Ming 2018). In contrast, tropospheric cooling due to increases in sulfates and other nonabsorbing aerosols, as well as negative aerosol indirect (e.g., cloud albedo, lifetime) effects, has been hypothesized to have the opposite effect, contributing to an equatorward contraction of the NH Hadley cell edge over the twentieth century (Ming et al. 2011; Allen and Ajoku 2016). The reported effects of tropospheric aerosols on recent tropical expansion differ greatly among studies, reflecting large uncertainties related to modeling aerosol processes and interactions with clouds and radiation.

Anthropogenic forcing does not necessarily need to be invoked to explain sizeable changes in the width of the tropics over several decades. In control integrations of climate models without any anthropogenic forcing, natural variability (internal atmospheric variability and coupled atmosphere-ocean variability) can produce 30 -yr trends that are comparable in magnitude to some estimates of the recent observed tropical expansion (Quan et al. 2014; Grise et al. 2018). In both observations and models, the tropics expand during La Niña events and contract during El Niño events (Oort and Yienger 1996; Seager et al. 2003; Lu et al. 2008; Stachnik and Schumacher 2011; Davis and Birner 2013; Nguyen et al. 2013; Guo and Li 2016), and idealized model experiments confirm that a narrow band of tropical heating (analogous to an El Niño event) produces a contraction of the tropics (Tandon et al. 2013). Likewise, the positive phase of the Pacific decadal oscillation (PDO), which has an El Niño-like SST pattern, is associated with a narrower tropical belt, and the negative phase of the PDO is associated with a wider tropical belt (e.g., Grassi et al. 2012). For this reason, a number of studies have concluded that the change in phase of the PDO in the late 1990s (from positive to negative) played a significant role in the recent expansion of the tropics (A14; Allen and Kovilakam 2017; Mantsis et al. 2017; Amaya et al. 2018), particularly from the late 1990s until the early 2010s (Adam et al. 2014; Waugh et al. 2015). However, coupled atmosphereocean variability may not be necessary to drive lowfrequency variability in tropical width, as internal atmospheric variability alone can also drive decades-long trends in the latitude of the Hadley cell edge in models (Kang et al. 2013; Simpson 2018).

Because of the diverse range of anthropogenic forcings and modes of natural variability that have been demonstrated to affect tropical width, the literature is filled with a wide range of conflicting statements about the predominant cause of the recent expansion of the tropics. Disparate methodologies across and within observational and modeling studies have contributed to a lack of clarity about the magnitude and causes of recent tropical width changes. Here, we aim to present a consistent analysis to help to resolve some of the discrepancies in the literature. In section 2, we describe our data and methods. Section 3 addresses the fidelity with which global climate models are able to capture observed variability and trends in the edge of the tropical belt. Section 4 discusses the attribution of the recent tropical widening and the relative roles of natural variability and anthropogenic forcing. Section 5 provides an outlook for tropical expansion in the twenty-first century, and section 6 summarizes our key conclusions.

\section{Data and methods}

\section{a. Data}

The primary observation-based datasets used in this study are the seven meteorological reanalyses listed in Table 1. We focus on the four most recent reanalyses [ERA-Interim; MERRA, version 2 (MERRA-2); JRA-55; and CFSR] but also include three older-generation reanalyses (ERA-40, NCEP-NCAR, and NCEP-DOE) for comparison with the results of JF09. In the reanalysis fields, we only examine the period starting from 1979 when the reanalyses are constrained by global satellite observations. Additionally, to calculate observed SST variability and trends, we use the Hadley Centre Sea Ice and SST dataset (HadISST1; Met Office Hadley Centre 2000; Rayner et al. 2003).

The primary model output used in this study is from 22 global climate models that participated in CMIP5 (WCRP 2011; Taylor et al. 2012). For each model, we use ensemble members from the following scenarios (see Table 2): 1) preindustrial control (hundreds of years of unforced variability), 2) historical (driven by 1850-2005 forcings), 3) RCP8.5 (driven by 2006-2100 projected forcings, which reach a radiative forcing of $8.5 \mathrm{~W} \mathrm{~m}^{-2}$ in excess of preindustrial levels in 2100), 4) historical GHG (driven by 1850-2005 GHG concentrations), 
TABLE 1. Listing of the reanalyses used in this study.

\begin{tabular}{|c|c|c|c|}
\hline Dataset & Resolution $\left({ }^{\circ}\right.$ lon $\times{ }^{\circ}$ lat $)$ & Time period & Citations \\
\hline ERA-40 & $1.125^{\circ} \times 1.125^{\circ}$ & 1979-2001 & $\begin{array}{l}\text { ECMWF (2004) } \\
\text { Uppala et al. (2005) }\end{array}$ \\
\hline ERA-Interim & $0.75^{\circ} \times 0.75^{\circ}$ & 1979-2016 & $\begin{array}{l}\text { ECMWF (2009) } \\
\text { Dee et al. (2011) }\end{array}$ \\
\hline NCEP-NCAR Reanalysis 1 & $2.5^{\circ} \times 2.5^{\circ}$ & 1979-2016 & $\begin{array}{l}\text { NCEP (1994) } \\
\text { Kalnay et al. (1996) } \\
\text { Kistler et al. (2001) }\end{array}$ \\
\hline NCEP-DOE Reanalysis 2 & $2.5^{\circ} \times 2.5^{\circ}$ & 1979-2016 & $\begin{array}{l}\text { NCEP (2002) } \\
\text { Kanamitsu et al. (2002) }\end{array}$ \\
\hline NASA MERRA-2 & $0.625^{\circ} \times 0.5^{\circ}$ & 1980-2016 & $\begin{array}{l}\text { NASA GMAO }(2015 a, b) \\
\text { Gelaro et al. }(2017)\end{array}$ \\
\hline JRA-55 & $1.25^{\circ} \times 1.25^{\circ}$ & 1979-2016 & $\begin{array}{l}\text { JMA (2013) } \\
\text { Kobayashi et al. (2015) }\end{array}$ \\
\hline $\begin{array}{l}\text { NCEP CFSR } \\
\text { CFSv2 }\end{array}$ & $0.5^{\circ} \times 0.5^{\circ}$ & $\begin{array}{l}1979-2010 \\
2011-16\end{array}$ & $\begin{array}{l}\text { Saha et al. }(2010 a, b) \\
\text { Saha et al. }(2012,2014)\end{array}$ \\
\hline
\end{tabular}

5) historical natural (driven by 1850-2005 solar and volcanic forcing), 6) historical aerosol (driven by 1850 2005 anthropogenic aerosol forcing), 7) historical ozone (driven by 1850-2005 stratospheric and tropospheric ozone concentrations), and 8) AMIP (atmosphere-only experiments driven by 1979-2008 forcings and observed SSTs and sea ice concentrations). We select this subset of 22 models because they each have a minimum number of three available ensemble members for the historical scenario, as well as available runs for both the AMIP and RCP8.5 scenarios.
We also examine output from the Community Earth System Model Large Ensemble (CESM-LE) project (NCAR 2014; Kay et al. 2015). Specifically, we use an 1800 -yr fully coupled preindustrial control run and 40 ensemble members for the period 1920-2100 forced with historical and RCP8.5 forcings. Each of these 40 ensemble members are exactly the same except for a different random small perturbation (round-off error) in their initial conditions, which allows for 40 realizations of natural variability over the twentieth and twenty-first centuries.

TABLE 2. Listing of the CMIP5 models and the number of ensemble members from each model used in this study. The following eight scenarios are used: pre-industrial control (PIC), historical (HIST), RCP 8.5, historical greenhouse gas only (GHG), historical natural forcing only (NAT), historical anthropogenic aerosol forcing only (AER), historical ozone forcing only (OZ), and AMIP. Models shown in Fig. 2 are bolded.

\begin{tabular}{|c|c|c|c|c|c|c|c|c|}
\hline Model name & PIC & HIST & RCP8.5 & GHG & NAT & AER & $\mathrm{OZ}$ & AMIP \\
\hline ACCESS1.0 & 1 & 1 & 1 & 0 & 0 & 0 & 0 & 1 \\
\hline ACCESS1.3 & 1 & 3 & 1 & 3 & 3 & 0 & 0 & 2 \\
\hline BCC_CSM1.1 & 1 & 3 & 1 & 1 & 1 & 0 & 0 & 3 \\
\hline BCC_CSM1.1(m) & 1 & 1 & 1 & 0 & 0 & 0 & 0 & 1 \\
\hline CanESM2 (CanAM4) & 1 & 5 & 1 & 5 & 5 & 5 & 0 & 4 \\
\hline CCSM4 & 1 & 8 & 1 & 3 & 4 & 3 & 2 & 6 \\
\hline CESM1(CAM5) & 1 & 3 & 1 & 1 & 3 & 3 & 3 & 2 \\
\hline CNRM-CM5 & 1 & 1 & 1 & 0 & 0 & 0 & 0 & 1 \\
\hline CSIRO Mk3.6.0 & 1 & 10 & 1 & 5 & 5 & 5 & 5 & 10 \\
\hline EC-EARTH & 1 & 1 & 1 & 0 & 0 & 0 & 0 & 1 \\
\hline FGOALS-g2 & 1 & 5 & 1 & 1 & 3 & 1 & 1 & 1 \\
\hline GFDL CM3 & 1 & 1 & 1 & 0 & 0 & 0 & 0 & 1 \\
\hline GISS-E2-R & 1 & 6 & 1 & 5 & 5 & 5 & 5 & 6 \\
\hline HadGEM2-ES (HadGEM2-A) & 1 & 4 & 1 & 4 & 4 & 0 & 0 & 6 \\
\hline IPSL-CM5A-LR & 1 & 1 & 1 & 0 & 0 & 0 & 0 & 1 \\
\hline IPSL-CM5A-MR & 1 & 1 & 1 & 0 & 0 & 0 & 0 & 1 \\
\hline MIROC5 & 1 & 1 & 1 & 0 & 0 & 0 & 0 & 1 \\
\hline MIROC-ESM & 1 & 1 & 1 & 0 & 0 & 0 & 0 & 1 \\
\hline MPI-ESM-LR & 1 & 1 & 1 & 0 & 0 & 0 & 0 & 1 \\
\hline MPI-ESM-MR & 1 & 1 & 1 & 0 & 0 & 0 & 0 & 1 \\
\hline MRI-CGCM3 & 1 & 1 & 1 & 0 & 0 & 0 & 0 & 1 \\
\hline NorESM1-M & 1 & 1 & 1 & 0 & 0 & 0 & 0 & 1 \\
\hline
\end{tabular}


TABLE 3. Statistics of annual-mean tropical width (distance between NH and SH tropical edges) for the period 1979-2016: mean (row 1), standard deviation (row 2), and regression on Niño 3.4 index (row 3) (i.e., by how much does tropical width vary for a -1-K SST anomaly in the Niño 3.4 region, corresponding to a La Niña event; Bamston et al. 1997; Trenberth 1997). OBS values reflect the range across four reanalyses (ERA-Interim, MERRA-2, JRA-55, CFSR). Note that the statistics for MERRA-2 are calculated for the period 1980-2016 and that CFSR (which ends in 2010) is extended with CFSv2 until 2016. Model values show the mean \pm 2 standard deviations across 22 CMIP5 models as based on the first ensemble member of each model's historical run extended with the corresponding RCP8.5 run until 2016. All time series are detrended with a linear fit prior to calculating the statistics in rows 2-3. Bold values indicate where the observational range does not fully overlap the model range. Correlation coefficients $r$ associated with the regression coefficients are listed in italics.

\begin{tabular}{|c|c|c|c|c|}
\hline & \multicolumn{2}{|c|}{ PSI500 } & \multicolumn{2}{|c|}{ USFC } \\
\hline & OBS & Model & OBS & Model \\
\hline Mean ( ${ }^{\circ}$ latitude $)$ & $60.15-63.83$ & $60.00 \pm 5.19$ & $62.18-62.98$ & $62.22 \pm 4.13$ \\
\hline Interannual standard deviation ( ${ }^{\circ}$ latitude) & $0.87-1.12$ & $0.72 \pm 0.32$ & $0.84-0.92$ & $0.84 \pm 0.30$ \\
\hline \multirow[t]{2}{*}{ Regression on ENSO (La Niña) $\left({ }^{\circ}\right.$ latitude $\left.\mathrm{K}^{-1}\right)$} & 0.72-1.00 & $0.48 \pm 0.46$ & $0.63-0.70$ & $0.61 \pm 0.38$ \\
\hline & $r=0.42-0.57$ & $r=0.46 \pm 0.41$ & $r=0.45-0.52$ & $r=0.49 \pm 0.32$ \\
\hline
\end{tabular}

\section{b. Methods}

We define the latitude of the edge of the tropical belt in each hemisphere using two metrics: 1) PSI500, the latitude where the zonal-mean meridional mass streamfunction at $500 \mathrm{hPa}$ changes sign in the subtropics, and 2) USFC, the latitude where the near-surface zonal-mean zonal wind changes sign from easterly to westerly in the subtropics. Interannual variations of the two metrics are significantly correlated in observations and models in both hemispheres (Davis and Birner 2017; Waugh et al. 2018), and at least in models, both metrics also correlate well with shifts in the zonal-mean precipitation minus evaporation $(P-E)$ field (Waugh et al. 2018). A physical rationale for the close correspondence between the PSI500 and USFC metrics is discussed in the appendix (see also Davis and Birner 2017).

In this study, we do not examine tropical expansion metrics based on outgoing longwave radiation or uppertropospheric fields (e.g., subtropical jet and tropopause) used by some previous studies. The variability and trends in these metrics correlate poorly with PSI500, USFC, and shifts in the zonal-mean $P-E$ field (Waugh et al. 2018), as the subtropical jet- and tropopause-based metrics are more strongly linked to the temperature field than the eddy momentum flux field (see discussion in Davis and Birner 2017). Consequently, tropical expansion defined from upper-tropospheric fields quantifies an aspect of recent circulation changes distinct from Hadley cell expansion (A. Solomon et al. 2016; Davis and Birner 2017; Waugh et al. 2018) and, while potentially important, is not the focus of this study.

We calculate the PSI500 and USFC metrics using the Tropical-Width Diagnostics (TropD) code package (Adam et al. 2018a,b). The metrics are calculated using annual-mean fields unless otherwise noted. For gridded datasets, linear interpolation between grid points is used to determine the locations of the zero crossings in the streamfunction and surface wind fields. Further calculation details are provided in Adam et al. (2018a,b) and in the appendix of Grise et al. (2018).

\section{Comparison of reanalyses and global climate models}

In this section, we address the fidelity with which global climate models capture observed variability and trends in the width of Earth's tropical belt. Here, the width of the tropical belt refers to the distance between the northern and southern edges of the tropics, as quantified by the PSI500 and USFC metrics. We use reanalyses to quantify observed variability and trends, keeping in mind that, while reanalyses assimilate observations, they also rely on a model-based component and may be subject to unphysical jumps related to model biases and changes in their observational input.

First, in Table 3, we list the annual-mean value of the width of the tropical belt and its interannual variability: that is, how large is year-to-year variability in tropical width and by how much does the tropical width covary with ENSO. We evaluate these statistics for the 1979-2016 period from four modern reanalyses (ERA-Interim, MERRA-2, JRA-55, and CFSR) and compare them to the statistics for the same period in the first historical ensemble member (r1i1p1) of the 22 CMIP5 models listed in Table 2. Because the historical runs of the models end in 2005, we extend each model's historical run with the first 11 years of its corresponding RCP8.5 run. Qualitatively similar statistics are found using the control runs of the models (not shown).

The results in Table 3 show that the mean value of tropical width measured by the PSI500 metric differs by over $3^{\circ}$ latitude among reanalyses, whereas the mean 
value of tropical width measured by the USFC metric differs by less than $1^{\circ}$ latitude. Calculating the USFC metric requires near-surface winds that are constrained in reanalyses by assimilated surface pressure and marine surface wind observations, at least some of which are shared among reanalysis centers (Fujiwara et al. 2017). In contrast, calculating the PSI500 metric requires the computation of a derived quantity (mass streamfunction) from the integration of zonal-mean meridional winds above $500 \mathrm{hPa}$, where the assimilated satellite radiances used to constrain reanalyses are not homogenized (Fujiwara et al. 2017). Additionally, mean meridional circulations derived from reanalyses generally do not conserve mass, implying that the PSI500 metric contains spurious artifacts from inhomogeneities in mass conservation that vary widely among reanalyses (Davis and Davis 2018).

Global climate models possess varying values for the mean and interannual variability of tropical width (Table 3). In general, the range of values indicated by models encompasses the observational estimates from reanalyses. One notable exception is the interannual variance of the PSI500 metric. As found by JF09 for CMIP3 models, the interannual standard deviation in global climate models is, on average, only $\sim 70 \%$ of that in reanalyses. However, some models do have very similar variance in the PSI500 metric as the reanalyses, including the CESM-LE (Quan et al. 2018).

Next, in Fig. 1, we compare the recent trends in the width of the tropics (as calculated from the seven reanalyses listed in Table 1) with trends from the control, historical, and AMIP runs of each CMIP5 model in Table 2. All trends are calculated using a linear least squares regression fit. In this figure, we show the reanalysis and model trends over two time periods: 19792005 (to allow for direct comparison of our results with those of JF09) and 1979-2016 (as in Table 3). We concentrate on comparing the reanalysis trends with trends from individual model ensemble members and not the mean of model ensemble members (as has been done in many previous studies). The mean of model ensemble members (Fig. 1, large black dots) is dominated by the response to forcing, as natural variability is averaged out across ensemble members. In contrast, the reanalyses and individual model ensemble members include the response to forcing plus any contribution from natural variability.

As mentioned in the introduction, JF09 concluded that global climate models could not capture the observed trends in tropical widening over the 1979-2005 period, suggesting that the models' circulations may not be sensitive enough to anthropogenic forcing. Here, in Fig. 1a, we reproduce their results based on the PSI500 metric (cf. Fig. 3 of JF09). The blue symbols in
Fig. 1a show the three reanalyses used by JF09: ERA-40, ${ }^{1}$ NCEP-NCAR, and NCEP-DOE. All three of these reanalyses show a tropical expansion of $0.9^{\circ}-1^{\circ}$ latitude decade ${ }^{-1}$ based on the PSI500 metric. This trend well exceeds the 97.5th percentile of trends from the control, historical, and AMIP runs of CMIP5 models (Fig. 1, black boxes). Similar results are found for CMIP3 models, as shown in JF09.

However, if newer reanalyses are used (Fig. 1, black symbols), we find that the trend estimates over the 1979-2005 period become smaller and much more variable $\left(\sim 0.2^{\circ}-0.8^{\circ}\right.$ latitude decade $\left.{ }^{-1}\right)$, and two of the reanalyses (JRA-55 and CFSR) now fall below the 97.5th percentile of trends from the AMIP model simulations (Fig. 1a; see also Adam et al. 2014). Furthermore, had JF09 considered the USFC metric, they would not have concluded that the observed trends exceeded those from model simulations (Fig. 1b). In fact, estimates of tropical widening based on the USFC metric in the newer reanalyses are modest $\left(\leq 0.25^{\circ}\right.$ latitude decade ${ }^{-1}$ ) and fall close to the multimodel mean values for the historical and AMIP CMIP5 runs (Fig. 1, large black dots). Similar conclusions hold for the 19792016 period (Figs. 1c,d), with more similar magnitudes of tropical expansion indicated by the PSI500 and USFC metrics among the newer reanalyses (on average, $0.25^{\circ}$ latitude decade ${ }^{-1}$ ).

The results in Fig. 1 are consistent with the recent studies of Garfinkel et al. (2015), Davis and Birner (2017), and Grise et al. (2018), who found that the magnitude of the recent tropical expansion does not fall outside the range of trends in fully coupled and prescribed-SST model simulations over recent decades. Furthermore, some of the reanalysis trends fall below the 97.5th percentile of trends in the control runs of the models (Fig. 1), suggesting that they could be explained by natural variability alone (Quan et al. 2014; Grise et al. 2018). Additionally, most of the trends from the newer reanalyses shown in Fig. 1 are not statistically significant at the $95 \%$ confidence level via the Student's $t$ test, accounting for autocorrelation as in Santer et al. (2000), only the PSI500 trends in ERA-Interim and the 1979-2016 USFC trends in JRA-55 pass this significance threshold. We note that these conclusions apply to annualmean, zonal-mean circulation shifts and may not apply to circulation changes in individual seasons or at individual longitudes (see Grise et al. 2018).

\footnotetext{
${ }^{1}$ ERA-40 is available in the annual mean until 2001, so its trend in Fig. 1 only covers the period 1979-2001. Trends in the NCEP reanalyses are similar between the 1979-2001 and 1979-2005 periods.
} 

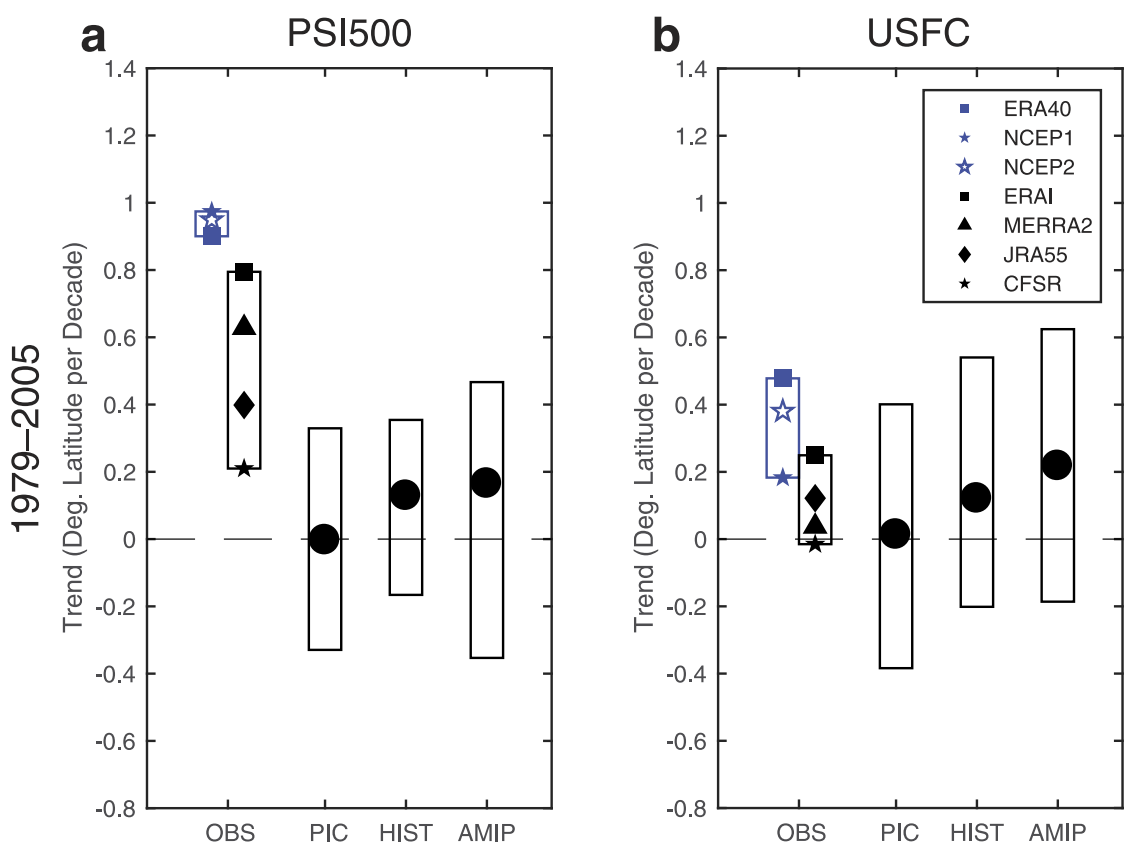

\section{C}

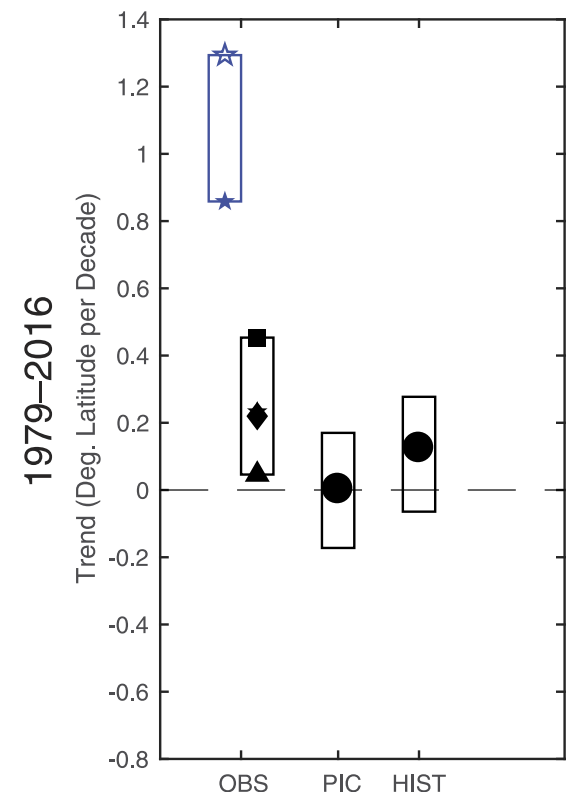

d

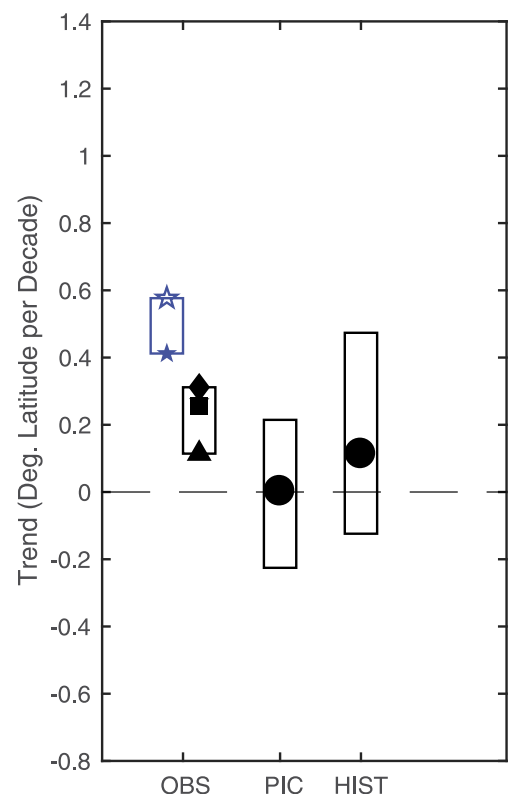

FIG. 1. Trends in annual-mean tropical width (i.e., the distance between the NH and SH tropical edges) based on two metrics, (a),(c) PSI500 and (b),(d) USFC, for the periods (top) 1979-2005 and (bottom) 1979-2016. In each panel, the OBS column denotes reanalysis trends, with the rectangles showing the range of reanalysis trends and the blue coloring denoting the reanalyses used by JF09. In each panel, the rightmost three columns show the mean (large black dot) and 2.5th-97.5th percentile value (rectangle) of CMIP5 model trends from all nonoverlapping 27-yr periods in (a) and (b) and 38-yr periods in (c) and (d) in the preindustrial control (PIC) runs, the first ensemble member (r1i1p1) for the historical (HIST) run of each model (in the bottom row, extended with the RCP8.5 run from 2005 to 2016), and the first ensemble member for the AMIP run of each model. The AMIP runs are only available for the 1979-2005 period. For (c) and (d), CFSR (which ends in 2010) is extended with CFSv2 until 2016. 
Overall, we find that JF09's conclusion that the observed tropical expansion is not captured by global climate models resulted from their use of the PSI500 metric in the older-generation reanalyses that were available at that time. The mean temperature and wind fields of older-generation reanalyses are often biased when compared to those from newer-generation reanalyses (Long et al. 2017), and spurious artifacts are likely introduced into the PSI500 metric in reanalyses from inconsistencies in assimilated satellite radiances (Fujiwara et al. 2017) and violations of mass conservation (Davis and Davis 2018). As a result, the mean value, interannual variability, and trends in the PSI500 metric differ across reanalyses, and the variance and trends in the PSI500 metric are generally larger in reanalyses than in models (Table 3; Fig. 1). By contrast, the mean value, interannual variability, and trends in the USFC metric, which is more closely constrained by surface observations, are in better agreement across reanalyses and are more consistent with models. However, the USFC metric has greater intermodel spread in trends in fully coupled model simulations than the PSI500 metric (cf. left and right columns of Fig. 1) and has smaller trends in reanalyses than most other metrics of tropical expansion (Fig. 1; Grise et al. 2018).

Given the results in this section, we focus on analysis of the USFC metric for the remainder of this paper. Results for the PSI500 metric are shown in the online supplemental material. By choosing the USFC metric as the primary metric in this study, we are not claiming here that it is superior to the PSI500 metric in measuring the location of the Hadley cell edge. In global climate models, the PSI500 metric remains an accurate measure of the Hadley cell edge. However, in reanalyses, large potential biases in the PSI500 metric, as discussed in this section and in Davis and Davis (2018), complicate an accurate comparison with models. Consequently, when reanalyses are compared with models, we recommend using an alternative metric (such as the USFC metric) that is more closely constrained by surface observations. As discussed in the appendix and in Davis and Birner (2017), there are strong physical reasons to support the usage of the USFC metric as a good measure of the location of the Hadley cell edge.

\section{Attribution of recent tropical expansion}

In this section, we examine global climate models to address the relative roles of natural variability and anthropogenic forcing in the recent expansion of the tropics. As shown in Fig. 1b, the historical runs of
CMIP5 models suggest that, on average, anthropogenic forcing contributed to a tropical expansion of $\sim 0.1^{\circ}$ decade $^{-1}$ from 1979 to 2005 . Over the same period, the AMIP runs of the models suggest that anthropogenic forcing and observed coupled atmosphereocean variability contributed to a tropical expansion of $\sim 0.2^{\circ}$ decade $^{-1}$ on average. At first glance, the larger mean trend in the AMIP runs seems to imply that observed coupled atmosphere-ocean variability over recent decades (including but not limited to changes in phase of ENSO and the PDO) approximately doubled the rate of tropical expansion from that expected from anthropogenic forcing alone (Adam et al. 2014; A14; Allen and Kovilakam 2017). We will return to this point in section $4 \mathrm{~b}$. First, in section $4 \mathrm{a}$, we examine the relative roles of different anthropogenic and natural forcings in contributing to tropical expansion in the models' historical runs.

\section{a. Anthropogenic and natural forcings}

To examine the relative roles of different anthropogenic and natural forcings in contributing to tropical expansion, we use the historical single-forcing runs of CMIP5 models, in which the models are perturbed with a number of 1850-2005 forcings individually: increasing GHGs, natural (solar and volcanic) forcing (NAT), anthropogenic aerosols (AER), and stratospheric and tropospheric ozone (OZ). Results are shown in Fig. 2 for the USFC metric. Qualitatively similar results are found for the PSI500 metric (see Fig. S1 in the online supplemental material). For reference, we also show trends from the preindustrial control (PIC), historical (HIST), and AMIP runs of the models, as well as trends from four modern reanalyses (as shown in Fig. 1). Here, we have separated the trends by hemisphere, as we expect stratospheric ozone depletion to have a greater role in the $\mathrm{SH}$ and anthropogenic aerosols to have a greater role in the $\mathrm{NH}$ (see introduction). To capture the seasonality of stratospheric ozone depletion, we show SH results for the DJF season (Fig. 2, bottom row), in addition to the annual mean (Fig. 2, middle row).

Figure 2 shows the CMIP5 trends for two periods: 1950-2005 (the longest period covered by all historical single-forcing runs in all models) in the left column and 1979-2005 (as in Fig. 1, top row) in the right column. Because most historical single-forcing runs do not extend beyond 2005, we do not examine the 1979-2016 period in this figure. The axes are different in the two columns to more clearly visualize the model ensemble spread in the left column. The right column of Fig. 2 is similar to Fig. 1 of A14 except that here we 1) use the USFC metric, 2) use a standard period of 1979-2005 for all runs, 3) show 


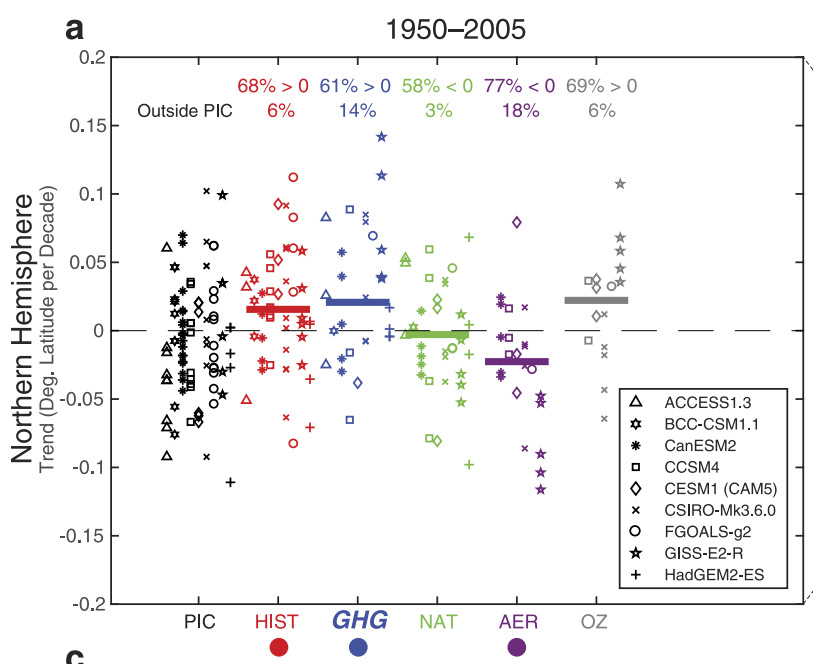

b

1979-2005
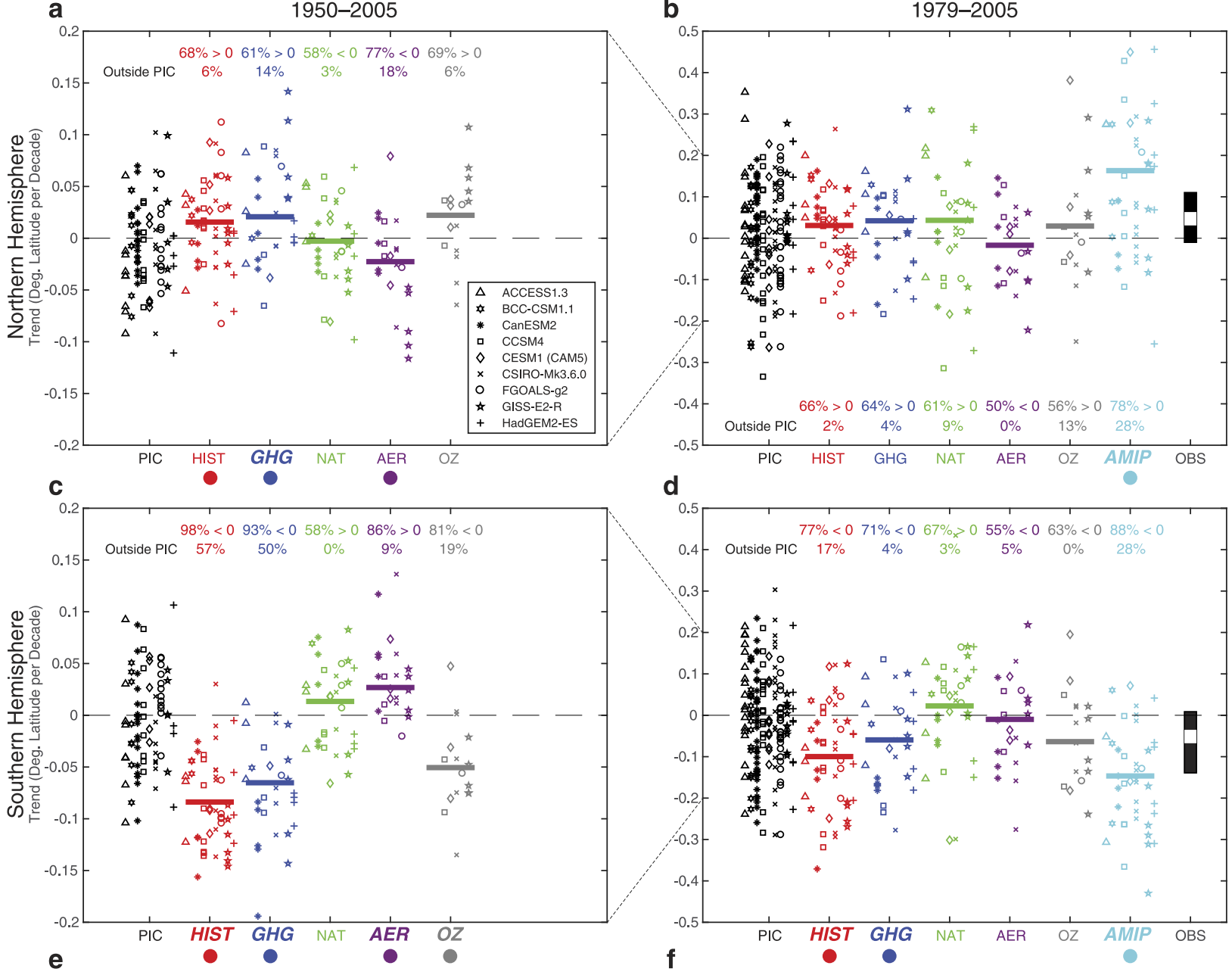

d
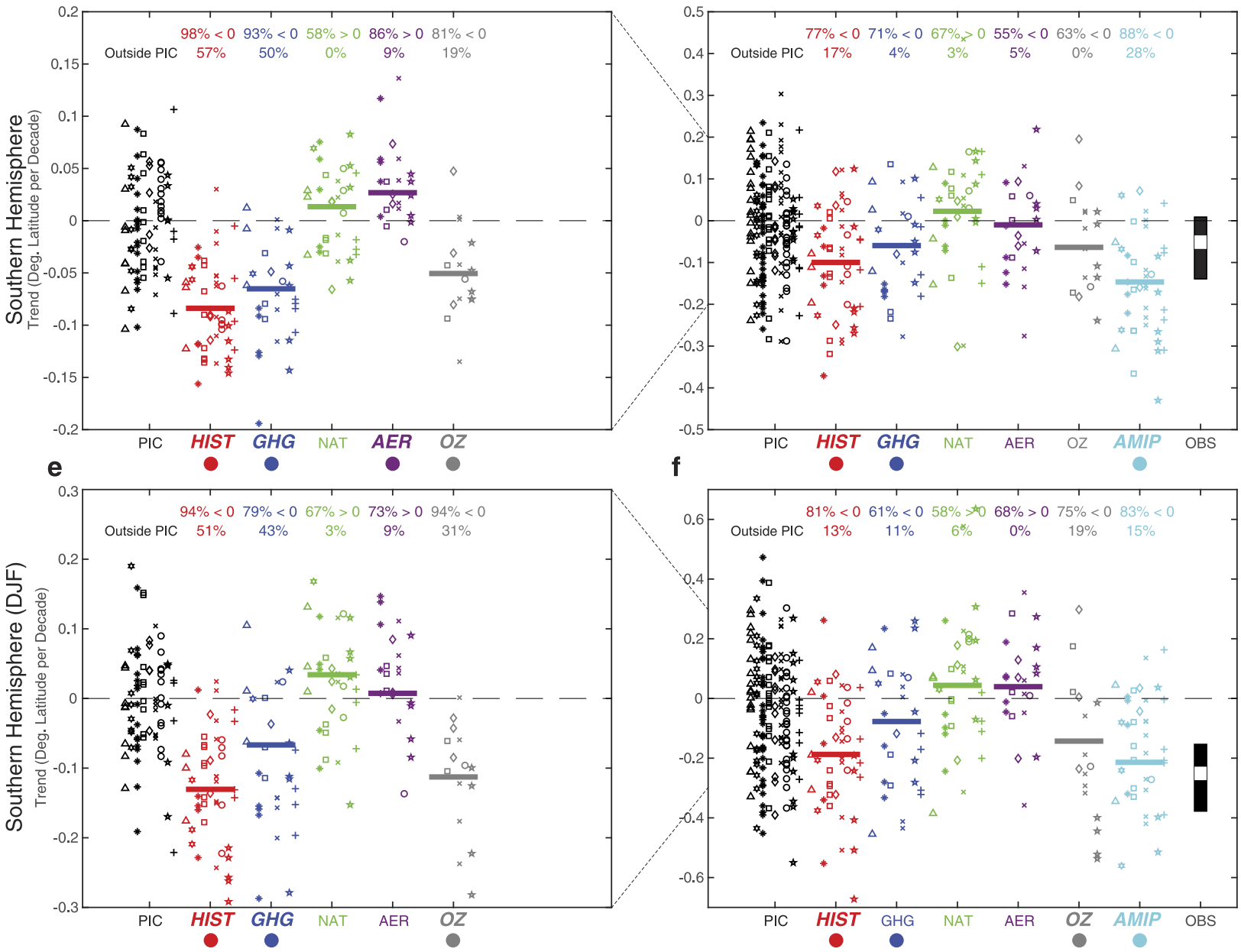

f

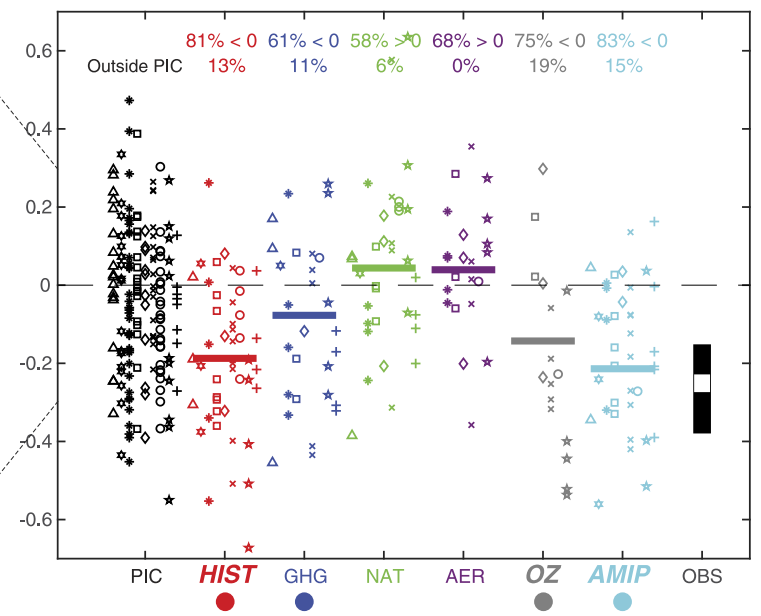

FIG. 2. Trends in the position of the (a),(b) NH annual-mean tropical edge, (c),(d) SH annual-mean tropical edge, and (e),(f) SH DJF-mean tropical edge as measured by the USFC metric, over (left) 1950-2005 and (right) 1979-2005. Positive trends indicate tropical expansion in the $\mathrm{NH}$, and negative trends indicate tropical expansion in the SH. Symbols show trends from individual ensemble members from nine CMIP5 models in the historical (HIST), historical single-forcing (GHG, NAT, AER, and OZ), and AMIP runs, and all nonoverlapping 56-yr periods in the left column and 27-yr periods in the right column in the preindustrial control (PIC) runs of the models. Horizontal lines show the mean over all model ensemble members. Filled black rectangles in the rightmost column give the range of OBS trends as estimated from four reanalyses (ERA-Interim, MERRA-2, JRA-55, CFSR), with the white square denoting the multireanalysis mean trend. Within each panel, text indicates the percentage of ensemble members with the same sign in the top row and that exceed the 2.5th-97.5th percentile of trends in the control runs in the bottom row. The names of the forcings below each column are in large italics if the forced response is statistically significant from control variability according to the procedure described in the text. Large dots below each column signify where the forced response is statistically significant from zero via the Student's $t$ test. The axes are different in the two columns to more clearly visualize the smaller magnitude of the trends in (a), (c), and (e). 
all individual model ensemble members (as opposed to showing the multimodel mean and its confidence bounds), and 4) confine our results to nine models. This last point deserves some explanation. Of the 22 models listed in Table 2, 6 did not perform any single-forcing runs [ACCESS1.0, BCC_CSM1.1(m), EC-EARTH, MIROC5, MPI-ESM-LR, MPI-ESM-MR]. Of the remaining 16 models, 7 include ozone forcing within their GHG single-forcing runs, and thus, these runs cannot be used to separate the influence of well-mixed GHGs from stratospheric ozone depletion. Nguyen et al. (2015) note that four of the models (GFDL CM3, MIROCESM, MRI-CGCM3, NorESM1-M) explicitly include ozone forcing in their GHG-only runs, and we have found an additional three models (CNRM-CM5, IPSL-CM5ALR, IPSL-CM5A-MR) that exhibit Antarctic stratospheric ozone depletion and cooling during austral spring in these runs. This therefore leaves the nine models that we examine in Fig. 2.

Over the 1979-2005 period, the multimodel mean values of tropical expansion from the historical and historical single-forcing runs (Fig. 2, horizontal lines) are $\sim 0.1^{\circ}$ decade $^{-1}$ or less in each hemisphere in the annual mean and compare well with the multimodel mean values shown in Fig. 1 of A14. One exception is the trend of the GHG single-forcing run in the SH: A14 find very similar multimodel mean trends in the historical and GHG-only runs, whereas our results show the trend of the GHG-only run to be approximately half of that of the historical run (Fig. 2d). This is because A14 used all available models with historical GHG-only runs (including those with ozone forcing), whereas we only use those historical GHG-only runs that exclude ozone forcing. Thus, the multimodel mean values of tropical expansion from the historical single-forcing runs are approximately additive in Fig. 2 (i.e., HIST $\approx \mathrm{GHG}+$ $\mathrm{NAT}+\mathrm{AER}+\mathrm{OZ}$ ), whereas they are not in A14. The additive nature of the forcings is clearer over the 1950 2005 period than over the 1979-2005 period, presumably because of the larger influence of natural variability on the model trends over the shorter time period (cf. scatter in left and right columns of Fig. 2).

The multimodel mean trends provide an estimate of the role of each forcing in recent tropical expansion, but these trends are very small and much smaller than the spread of trends across model ensemble members for each scenario. Thus, it is plausible that a particular forcing does not have a significant influence on the width of the tropics but that a grouping of ensemble members driven by that forcing may possess a small positive or negative mean trend by chance. To address this issue, in Fig. 2, we test whether the mean of ensemble members driven by each forcing is significantly different from zero via the Student's $t$ test (Fig. 2, large dots). To show the degree of consistency across models, we also list the percentage of model ensemble members driven by each forcing that possess trends of the same sign.

In many cases, the control runs of the models possess equally large trends over equivalent lengths of time without external (i.e., GHG or ozone) forcing (Fig. 2; cf. trends in PIC column with other columns). To test whether the ensemble members driven by a particular forcing are distinguishable from control variability in the models, we compare the trends from the forced ensemble members of the models with trends from an equivalent number of randomly sampled periods from the control runs of the same models and evaluate whether the two subsets of trends are significantly different from one another via the Student's $t$ test (Fig. 2, italicized forcings). Repeated random sampling of different periods from the control runs yields similar results (not shown). We also list the percentage of ensemble members driven by each forcing that fall outside of the 2.5th-97.5th percentile of trends in the models' control runs.

In the NH, CMIP5 models indicate that anthropogenic forcing (particularly increasing GHGs) contributed to a very small poleward shift in the tropical edge $\left(<0.05^{\circ}\right.$ decade $\left.^{-1}\right)$, which is statistically different from zero over the 1950-2005 period (Fig. 2a). However, such a small forced signal is only detectable using a large ensemble of model simulations. When comparing the trends in individual ensemble members from the models' control and historical runs (Figs. 2a,b, PIC and HIST columns), any small net influence of anthropogenic forcing on $\mathrm{NH}$ tropical width during the late twentieth century is not discernible within a background of large natural variability, as virtually all of the trends from the forced ensemble members fall inside the 2.5th-97.5th percentile of trends from the models' control runs (see section 5 for similar results from CESM-LE).

There is some suggestion that anthropogenic aerosols opposed increasing GHGs and contributed to a small equatorward shift of the $\mathrm{NH}$ tropical edge over the 1950-2005 period (Fig. 2a), with the largest trends coming from 1950 to 1979 (not shown). This is consistent with the results of A14 and Allen and Ajoku (2016), who argued that sulfates and other nonabsorbing aerosols acted to contract the tropics over this period. However, in Fig. 2a, the aerosol-forced trend largely comes from one model (GISS-E2-R), and if this model is removed, the aerosol influence is no longer significantly different from zero. Brönnimann et al. (2015) concluded that multidecadal SST variability, not the direct radiative forcing of aerosols, contributed to an equatorward shift of the NH tropical edge from 1945 to 1980. 
Over the 1979-2005 period, the net aerosol influence on the NH tropical width is small and not statistically significant (Fig. 2b, AER), possibly because of the compensating effects of black carbon and nonabsorbing aerosols (see Allen and Ajoku 2016). We also find that tropospheric ozone (which is included in the OZ forcing) does not have a statistically significant influence on the NH tropical width over this period (Fig. 2b, OZ), which is in contrast to the results of Allen et al. (2012b) from CMIP3 models. The aerosols and tropospheric ozone found in global climate models often differ substantially from observations (e.g., Bond et al. 2013; Young et al. 2018), and parameterizations of aerosolcloud interactions are highly uncertain and vary widely across models (e.g., Quaas et al. 2009). Consequently, if aerosol forcing, tropospheric ozone, or aerosol indirect effects are incorrectly represented in most CMIP5 models, then their actual influence on tropical expansion may be very different than that indicated in Fig. 2 .

In the SH, CMIP5 models indicate that anthropogenic forcing contributed to a statistically significant poleward shift in the tropical edge $\left(\sim 0.1^{\circ}\right.$ decade $\left.^{-1}\right)$ over both the 1950-2005 and 1979-2005 periods. Unlike in the $\mathrm{NH}$, a sizeable fraction of the trends from the forced ensemble members fall outside of the 2.5th-97.5th percentile of trends from the models' control runs (cf. PIC and HIST columns in Fig. 2c; see also Quan et al. 2014), and thus, the models suggest that the forced trends in the SH are large enough to be distinguishable from internal variability (particularly over the 1950 2005 period). The trends in the models' historical runs largely arise from two forcings: GHGs and ozone (Fig. 2c). There is also some suggestion that aerosols contributed to a small equatorward shift of the $\mathrm{SH}$ tropical edge over the 1950-2005 period (Fig. 2c, AER). However, using a larger subset of models, Steptoe et al. (2016) concluded that this signal was model dependent and nonrobust (see also Choi et al. 2019).

In the annual mean, the influence of GHG and ozone forcing on SH tropical expansion is roughly comparable (Figs. 2c,d), but when the DJF season is examined individually, ozone forcing has a slightly larger influence (Figs. 2e,f). This result is consistent with a number of past studies, which have concluded that stratospheric ozone depletion played a significantly larger role than increasing GHGs in SH tropical expansion during DJF over the late twentieth century (Son et al. 2010; Polvani et al. 2011a; McLandress et al. 2011; Min and Son 2013; Garfinkel et al. 2015; Waugh et al. 2015). The influence of stratospheric ozone depletion on the recent $\mathrm{SH}$ tropical expansion varies widely by model, as some models have a very weak ozone hole compared to observations while other models have too strong of an ozone hole (Eyring et al. 2013). All models shown in Fig. 2 explicitly prescribe their stratospheric ozone concentrations; models with interactive stratospheric ozone chemistry generally show larger impacts of stratospheric ozone depletion on the tropospheric circulation (Eyring et al. 2013).

\section{b. Natural variability}

Next, we return to the role that natural variability has played in the recent observed tropical expansion. Figure 2 (right column) shows the spread of ensemble members from the AMIP runs of CMIP5 models, in which observed SSTs and sea ice concentrations are prescribed. As noted above, the mean rate of tropical expansion in the AMIP runs is roughly twice that of the fully coupled historical runs (Fig. 1b). The tropical expansion in the AMIP runs is of similar magnitude $\left(\sim 0.15^{\circ}\right.$ decade $\left.^{-1}\right)$ in each hemisphere (Figs. 2 b,d $)$, and interestingly, some reanalyses also show symmetric rates of tropical expansion in the two hemispheres [Davis and Rosenlof 2012; Fig. 2, observed (OBS)]. In contrast, the tropical expansion in the fully coupled historical runs is dominated by the $\mathrm{SH}$ (as discussed in section $4 a$; cf. Figs. $2 b$ and $2 d$ ). Consequently, the discrepancy between the AMIP and historical runs is larger in the $\mathrm{NH}$ (Fig. 2b), suggesting that observed coupled atmosphere-ocean variability has played a larger role in recent tropical expansion in the $\mathrm{NH}$ (cf. Fig. 8 of Allen and Kovilakam 2017). However, the hemispheric symmetry of the AMIP trends appears to be metric dependent, as the NH trends in the AMIP runs are not as large when examining the PSI500 metric (Fig. S1b).

The observed SSTs used to prescribe the AMIP runs include both the signature of climate forcings and internal variability. Figure 3a shows the SST trends over the 1979-2005 period from the HadISST1 dataset. Most of the $\mathrm{NH}$ and tropical oceans show a warming trend consistent with the concurrent rise in globalmean surface temperature, but note also that there is a cooling trend over the eastern Pacific Ocean. The asymmetric SST trends over the Pacific Ocean with warming over the western subtropical Pacific and cooling in the eastern Pacific are consistent with a change in phase of the $\mathrm{PDO}^{2}$ from positive to negative

\footnotetext{
${ }^{2}$ Given their signature in both the NH and SH, the SST patterns in Fig. 3 may be more accurately described in terms of the interdecadal Pacific oscillation (IPO). We retain the usage of the term PDO in this study to be consistent with prior tropical expansion studies.
} 


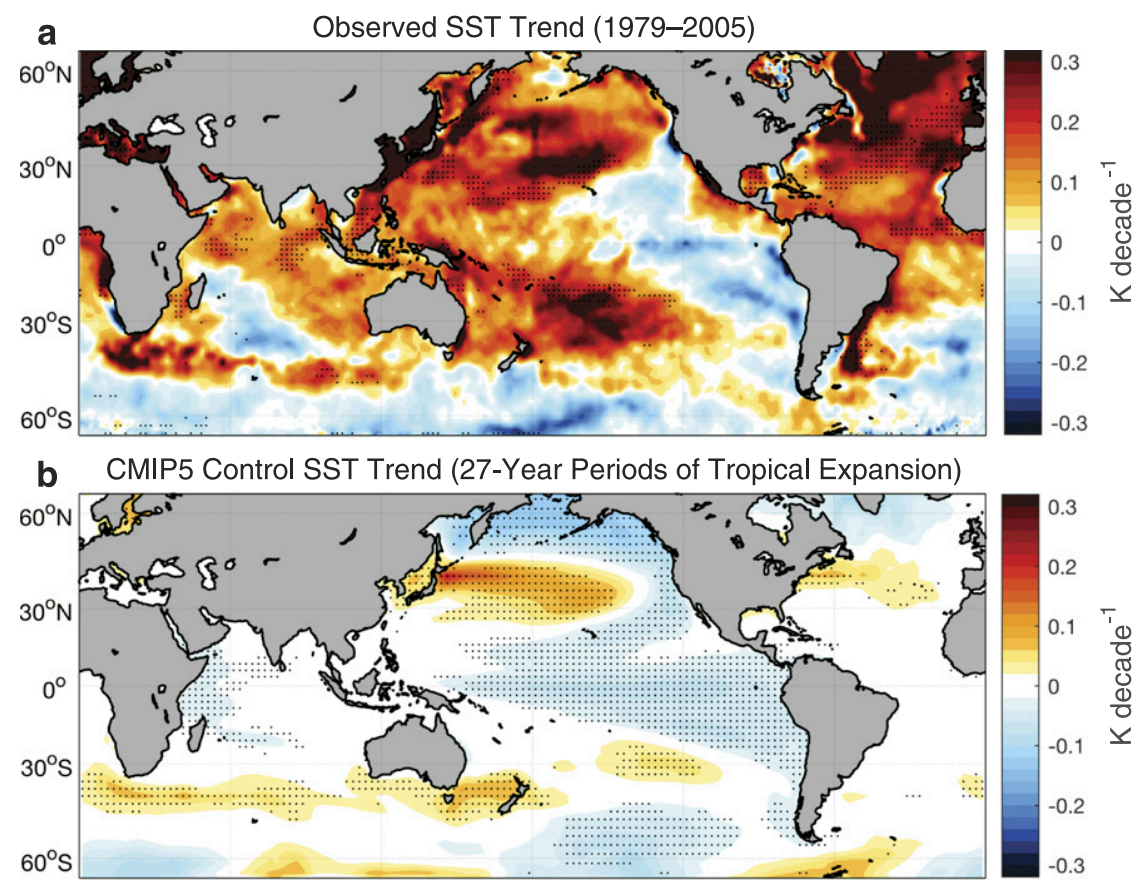

FIG. 3. (a) Observed 1979-2005 annual-mean SST trends from the HadISST1 dataset. (b) Regressions of SST trends from 27-yr periods in the CMIP5 models' control runs on the coinciding trend in the annual-mean tropical width (as measured by the USFC metric). Magnitudes correspond to the SST trends associated with a $0.2^{\circ}$ decade $^{-1}$ tropical expansion in the control runs of the models. Results are shown for the mean of all 22 CMIP5 models listed in Table 2. Stippling in (a) indicates where the observed trends are 95\% significant via a two-sided Student's $t$ test, and stippling in (b) indicates where at least $80 \%$ of the models agree on the sign of the regression coefficient.

in the late 1990s. The cooling in the eastern equatorial Pacific may also reflect a century-long SST trend in the region (Cane et al. 1997; Karnauskas et al. 2009; Coats and Karnauskas 2017). Several studies have suggested that the recent change in phase of the PDO was driven by aerosol forcing (A14; Smith et al. 2016), but Newman et al. (2016) concluded that the recent PDO behavior is consistent with natural variability and that the externally forced component of the PDO has been negligible. We also find that, when a sufficiently large sample size of models is examined, there is no clear trend in the PDO over the historical period (not shown), and thus in our discussion below, we assume that the recent phase change of the PDO was primarily due to natural variability.

Figure $3 \mathrm{~b}$ shows that periods of large tropical expansion in the control runs of models are on average associated with SST trends that resemble the negative phase of the PDO (see also Allen and Kovilakam 2017 and Mantsis et al. 2017). Consequently, both the forced (global warming) and unforced (PDO-like) components of the recent observed SST trends (Fig. 3a) contribute to tropical expansion in the AMIP runs of
CMIP5 models (Fig. 2, right column). Using an ensemble of AMIP simulations in a single model, Allen and Kovilakam (2017) concluded that the unforced (PDO-like) component of the observed SST trends is more strongly linked to the recent tropical expansion in the NH. They also found similar rates of tropical expansion in so-called pacemaker model runs, which use a fully coupled ocean model, but in the central and eastern tropical Pacific Ocean, the model SSTs are relaxed to observed anomalies from climatology (Kosaka and Xie 2013). As discussed by Amaya et al. (2018), the recent phase change of the PDO has garnered a lot of attention for its role in the global surface temperature warming "hiatus" of the early 2000s (Kosaka and Xie 2013, 2016), but the same PDO variability has also likely enhanced tropical expansion from the late 1990s until the early 2010s (Adam et al. 2014; Waugh et al. 2015).

While, on average, models suggest that unforced coupled atmosphere-ocean variability is the largest contributor to recent tropical widening trends in the $\mathrm{NH}$ (Fig. 2b), there remains a great deal of variance across model ensemble members (Fig. 2b, AMIP; see also Garfinkel et al. 2015). Even in the presence of 

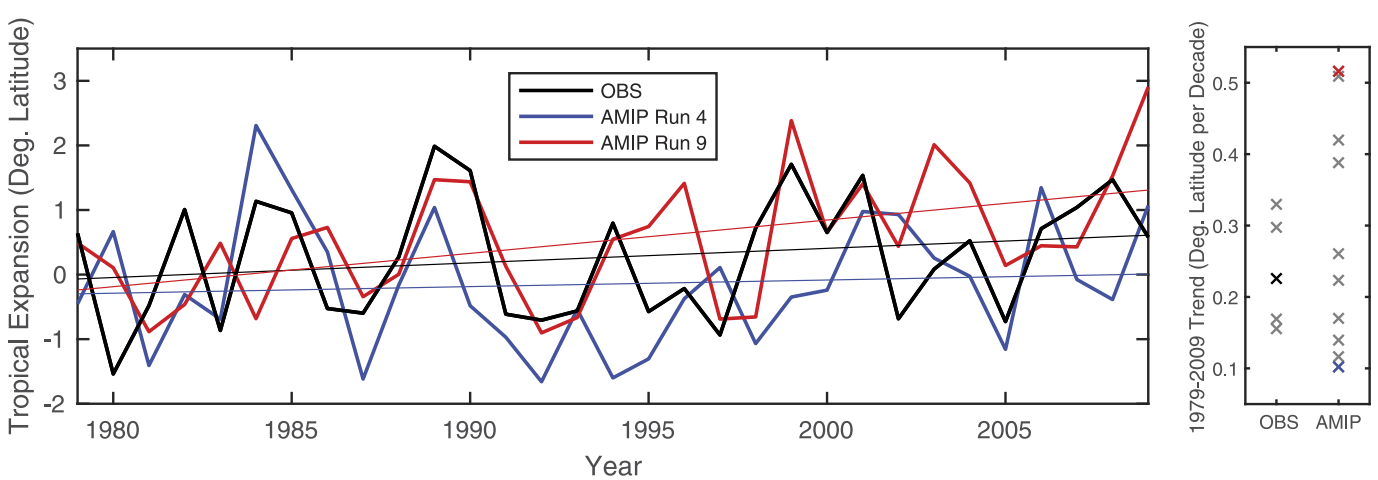

FIG. 4. (left) The 1979-2009 time series of annual-mean tropical width (i.e., the distance between the NH and SH tropical edges) based on the USFC metric for multireanalysis mean (black; ERA-Interim, MERRA-2, JRA-55, CFSR) and individual AMIP ensemble members from the CSIRO Mk3.6.0 model (blue, red). The time series are plotted as anomalies from their 1979-1988 mean. (right) Scatterplot of 1979-2009 trends from all reanalysis products (black cross: reanalysis mean) and all 10 AMIP ensemble members from the CSIRO Mk3.6.0 model. The red and blue crosses correspond to the two ensemble members shown in the left panel.

large changes in the PDO, internal atmospheric variability, such as the annular modes (Kang et al. 2013) or other variability in midlatitude eddy activity (Sun et al. 2019), can offset or enhance any tropical widening associated with the SSTs. In Fig. 4, we demonstrate this fact by comparing the observed tropical expansion with the tropical widening trends from 10 AMIP ensemble members from the CSIRO Mk3.6.0 model, the CMIP5 model with the greatest number of AMIP ensemble members available. Some ensemble members show much larger rates of tropical expansion than reanalyses (Fig. 4, red line), some show similar rates of expansion as the reanalyses, and some show very little tropical expansion at all (Fig. 4, blue line). Note, however, that the range of internal atmospheric variability may be improperly represented in AMIP runs, as prescribed-SST model runs have a poor representation of air-sea surface fluxes (e.g., Bretherton and Battisti 2000; Wu and Kirtman 2005).

The fact that the PDO has switched to its negative phase in recent decades does not necessarily guarantee that the tropics would have expanded over this period. In both observations and models, coupled atmosphereocean variability explains less than $50 \%$ of the interannual variance in the width of the tropics (Simpson 2018; Sun et al. 2019), and even in model runs with fixed climatological SSTs, tropical width can exhibit large decadal variability (Simpson 2018). Thus, internal atmospheric variability complicates the direct comparison of observed trends with the multimodel mean of the AMIP runs from CMIP5 models.

\section{c. Summary}

In summary, we examined the historical, historical single-forcing, and AMIP runs from CMIP5 models to assess the likely causes of the recent observed expansion of the tropics. The models indicate that, on average, the largest contributing factors are PDO-like internal variability, stratospheric ozone depletion during DJF in the $\mathrm{SH}$, and increasing GHGs in the $\mathrm{SH}$. This is consistent with the findings of numerous previous studies, as noted above. However, it is misleading to contrast the observed trends with a multimodel mean or a mean of ensemble members from a single model, as this averages out the contribution from internal atmospheric variability and, in the case of fully coupled models, coupled atmosphereocean variability. Instead, it is more appropriate to contrast the observed trends with the spread of individual model ensemble members (see also Garfinkel et al. 2015). When this is done, it becomes difficult to distinguish which of the forcings could be driving the observed trends (cf. model scatter with reanalysis trends in Fig. 2). Furthermore, many reanalysis trends fall inside the range of trends from the models' control runs (Figs. 1, 2), suggesting that at least some of the observed trends have not yet emerged from natural variability.

\section{Outlook for twenty-first century}

Given the large natural variability in the width of the tropics, in this section, we ask, When (if at any time) during the twenty-first century will anthropogenically forced tropical expansion emerge from natural variability? To answer this question, we define a "time scale of emergence" using the criterion of Hawkins and Sutton (2012). They consider the forced response to emerge from natural variability when it exceeds a onestandard-deviation threshold of the variability in a climate without anthropogenic forcing. Similar conclusions are reached using the methods described in section 4 a (not shown). 
Figure 5 utilizes the CESM-LE to illustrate the time scale of emergence of forced tropical expansion in the twenty-first century. Results for CMIP5 models are shown in Fig. S2. In Fig. 5, natural variability is defined using the interannual standard deviation from the 1800-yr CESM-LE control run (Fig. 5, gray shading), and the forced response is defined using the average over all 40 ensemble members of the CESM-LE over the period 1920-2100 (Fig. 5, red line). To interpret the results below, it is important to note that the CESM-LE 1) possesses a realistic depiction of twentieth-century stratospheric ozone depletion (Marsh et al. 2013; Kay et al. 2015) and 2) assumes a high-GHG-emissions scenario (RCP8.5) for the twenty-first century. Future tropical expansion is smaller in moderate-emissions scenarios (Hu et al. 2013; Tao et al. 2016).

In the $\mathrm{SH}$, the forced response exceeds the onestandard-deviation threshold in the early twenty-first century (Fig. 5b; see also Fig. S2 for CMIP5 models), indicating that forced tropical expansion in the $\mathrm{SH}$ may have already emerged from natural variability (consistent with our findings in Fig. 2). This early time scale of emergence in the annual mean arises largely from the DJF season when stratospheric ozone depletion has played a key role in forcing the recent circulation trends (Figs. 2e,f). The CESM-LE indicates that forced $\mathrm{SH}$ tropical expansion during DJF may have emerged from natural variability as early as the late 1980s (Fig. 5c; Thomas et al. 2015; Solomon and Polvani 2016), whereas it will not emerge from natural variability during other seasons until the mid-twenty-first century (not shown). Using a more stringent two-standard-deviation threshold (Fig. 5, dashed black lines), the forced tropical expansion in the $\mathrm{SH}$ would not emerge from natural variability in the annual mean until 2060 (Fig. 5b). This time frame is consistent with the recent findings of Quan et al. (2018), who find a time scale of emergence of tropical expansion from 1980 conditions around the year 2060.

The emergence of forced tropical expansion in the $\mathrm{SH}$ during the twenty-first century is complicated by the recovery of the Antarctic ozone hole. While increasing GHGs would continue to force the SH tropical edge poleward throughout the twenty-first century, the projected recovery of the Antarctic ozone hole in the early- to mid-twenty-first century will counteract the GHG forcing during the DJF season and act to contract the SH tropical edge equatorward over this period (Son et al. 2009; McLandress et al. 2011). As a result, the rate of $\mathrm{SH}$ tropical expansion during DJF is projected to slow until the mid-twenty-first century (Fig. 5c; Polvani et al. 2011b; Barnes et al. 2014).

In contrast to the tropical expansion in the SH, Fig. 5a shows that the forced tropical expansion in the $\mathrm{NH}$ does a
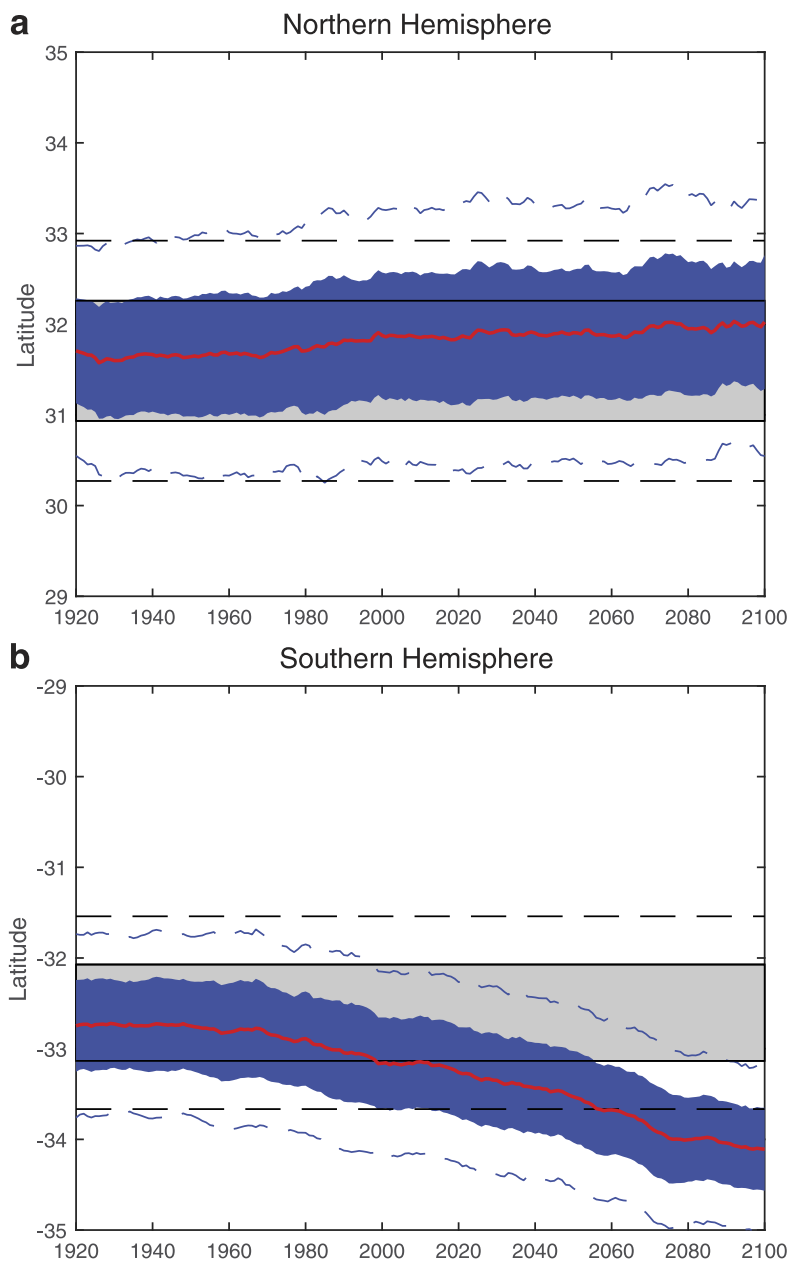

c

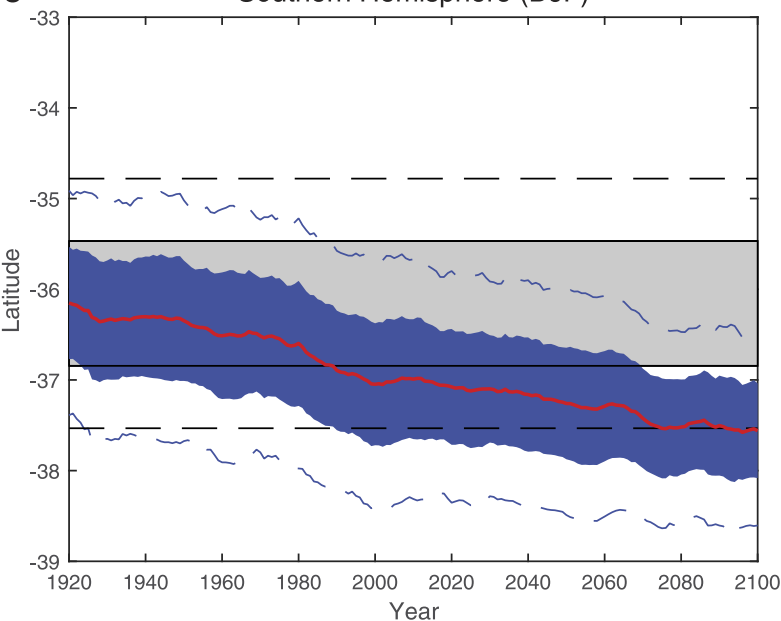

FIG. 5. Latitudes of (a) NH annual-mean tropical edge, (b) SH annual-mean tropical edge, and (c) SH DJF-mean tropical edge over the 1920-2100 period from the CESM-LE, as measured by the USFC metric. The 40-member ensemble mean (smoothed with a 10 -yr running mean) is in red, with the one- and two-standarddeviation ranges across ensemble members marked with blue shading and blue dashed lines, respectively. The one- and twostandard-deviation ranges in the control run of the model are marked with gray shading and black dashed lines, respectively. 
not emerge from natural variability in the twenty-first century in the CESM-LE. This result is not unique to the USFC metric, as similar results are found for other metrics (see Fig. S3 for the PSI500 metric). Furthermore, interannual variability in tropical width in the CESM-LE is found to be reasonable when compared to observations (Quan et al. 2018). Some CMIP5 models do show the emergence of forced tropical expansion in the $\mathrm{NH}$ from natural variability in the twenty-first century, but in the multimodel mean, the forced tropical expansion still only weakly exceeds the one-standarddeviation threshold of natural variability around the year 2095 (Fig. S2a). Overall, we conclude that, under the RCP8.5 scenario, forced tropical expansion in the $\mathrm{SH}$ will exceed natural variability in the twenty-first century (and may have already done so by some measures), whereas forced tropical expansion in the $\mathrm{NH}$ may not. We note that this conclusion is in contrast to Amaya et al. (2018), who find that forced tropical expansion will emerge in both hemispheres by approximately 2020 . However, Amaya et al. (2018) only consider ENSO-like SST variability in their estimate of natural variability, and as we have discussed above, internal atmospheric variability also plays a large role in interannual variability of tropical width (see also Simpson 2018).

Why is future tropical expansion projected to strongly emerge from natural variability in the $\mathrm{SH}$ but not the NH? First, natural variability in the tropical edge is slightly larger in the $\mathrm{NH}$ (interannual standard deviation of $0.7^{\circ}$ ) than in the SH (interannual standard deviation of $0.5^{\circ}$ ), making the same forced signal more easily detectable in the $\mathrm{SH}$. This hemispheric difference is also found in model runs with fixed climatological SSTs, suggesting that the greater natural variability in the $\mathrm{NH}$ arises from internal atmospheric variability (see Quan et al. 2014). Second, and more importantly, the projected tropical widening from 1920 to 2100 is approximately 3-4 times larger in the SH $\left(1.3^{\circ}\right.$ in the CESM-LE; $1.6^{\circ}$ in the CMIP5 multimodel mean) than in the NH (0.3 ${ }^{\circ}$ in the CESM-LE; $0.6^{\circ}$ in the CMIP5 multimodel mean; Fig. 5 and Fig. S2). The larger tropical widening in the $\mathrm{SH}$ is a common characteristic of CMIP5 models and has been noted in previous studies (Hu et al. 2013; Tao et al. 2016).

By the year 2100, the ozone hole is projected to have fully recovered, so the dominant driver of the hemispheric asymmetry is increasing GHGs. Indeed, CMIP5 models forced only by a quadrupling of $\mathrm{CO}_{2}$ show much larger tropical widening in the $\mathrm{SH}$; only during the fall ( $\mathrm{SON}$ ) season is the projected $\mathrm{NH}$ tropical widening as large as that in the SH (Davis et al. 2016; Grise and Polvani 2016). Future research is needed to better understand the larger sensitivity of the zonal-mean circulation to $\mathrm{GHG}$ forcing in the $\mathrm{SH}$, but potential factors at play are the more zonally symmetric flow in the $\mathrm{SH}$, the larger land-sea temperature contrast and monsoonal circulations in the $\mathrm{NH}$, and the large Arctic surface temperature amplification and sea ice loss in the NH (Grise and Polvani 2014; Simpson et al. 2014; Deser et al. 2015). In the $\mathrm{NH}$, one might anticipate a competing "tug of war" that would limit the future poleward circulation shift, as tropical uppertropospheric warming would act to shift the circulation poleward and Arctic surface temperature amplification would act to shift the circulation equatorward (e.g., Butler et al. 2010; Barnes and Polvani 2015; Harvey et al. 2015; Shaw et al. 2016).

Finally, even though the forced component of tropical expansion in the $\mathrm{SH}$ is very large under the RCP8.5 scenario, the SH tropical edge may still contract over 30-yr intervals during the twenty-first century in this scenario, which could cause some to mistakenly conclude that tropical expansion has stopped. Figure 6 shows the distribution of trends in the latitude of the SH tropical edge over the next 30 years (2020-50) from the 40 members of the CESM-LE. While the majority ( $75 \%)$ of ensemble members show tropical expansion over this period, the remainder contract, including the one highlighted in red in Fig. 6. So, even in the presence of a large forced trend, it is possible for a 30-yr trend of the opposite sign to arise from natural variability. As noted above, the projected recovery of the Antarctic ozone hole would also act to contract the SH tropical edge equatorward over this period, but similar results to those shown in Fig. 6 can be found for the 2070-2100 period after the ozone hole is projected to have fully recovered.

\section{Conclusions}

In this synthesis paper, we reexamine a number of the key conclusions in the last decade of literature on the recent expansion of Earth's tropical belt. Based on the existing literature and our analysis above, we reach the following conclusions:

1) The tropical expansion indicated by most modern reanalyses since 1979 is modest $\left(\sim 0.2^{\circ}-\right.$ $0.4^{\circ}$ latitude decade ${ }^{-1}$ ) and within the bounds of global climate model simulations of the late twentieth and early twenty-first century (Fig. 1; Adam et al. 2014; Garfinkel et al. 2015; Davis and Birner 2017; Grise et al. 2018). Earlier studies (JF09; Hu et al. 2013) had concluded that models were unable to capture the observed rates of tropical expansion. This was because of their use of older-generation reanalyses (which are often biased compared to 

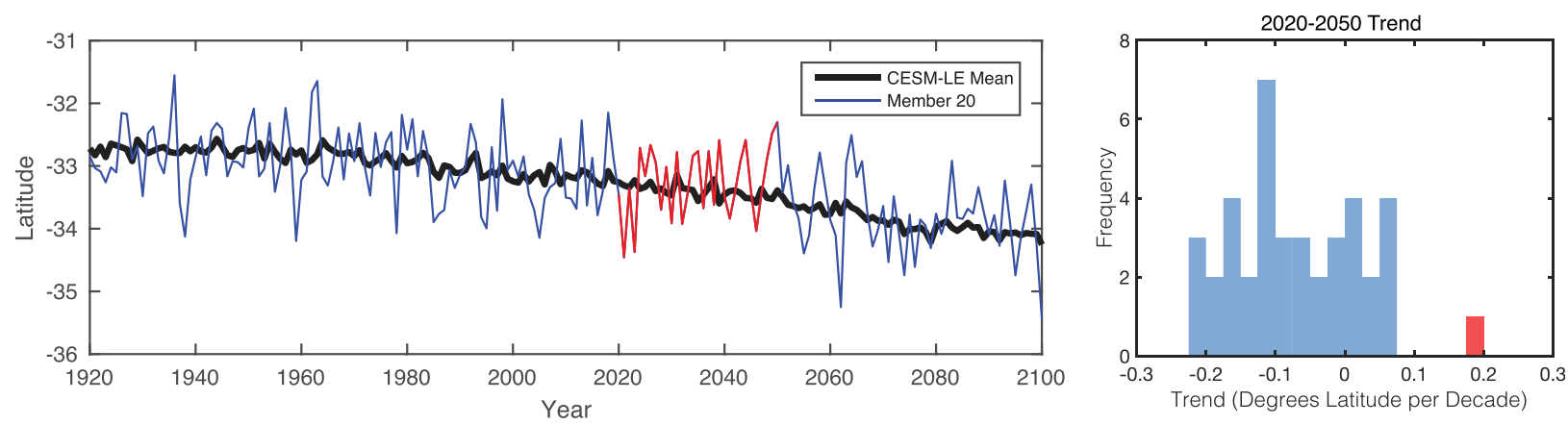

FIG. 6. (left) Annual-mean latitude of the SH tropical edge over the 1920-2100 period from the CESM-LE, as measured by the USFC metric. The 40-member ensemble mean is in black, and an individual ensemble member (member 20) is in blue. The period 2020-50 is highlighted in red. (right) Histogram of the trend over the 2020-50 period from all 40 ensemble members. Member 20 is in red.

newer reanalyses; see Long et al. 2017 and Davis and Davis 2018) and the PSI500 metric (which is more uncertain in reanalyses than surface-based metrics; Table 3).

2) Global climate models suggest that anthropogenic forcing played a significant role in the poleward shift of the SH tropical edge over the second half of the twentieth century because of contributions from increasing GHGs and, during the summer season, stratospheric ozone depletion (Figs. 2c-f; Polvani et al. 2011a; Waugh et al. 2015). Anthropogenically forced tropical expansion has likely already emerged from natural variability during DJF, in large part because of stratospheric ozone depletion (Fig. 5c; Thomas et al. 2015; Solomon and Polvani 2016), and with continued GHG increases, is projected to emerge from natural variability during all seasons by the midtwenty-first century (Quan et al. 2018).

3) Models suggest that anthropogenic forcing did not play a large net role in shifts of the $\mathrm{NH}$ tropical edge over the second half of the twentieth century (Figs. 2a,b; see also Quan et al. 2014), and anthropogenically forced tropical expansion in the $\mathrm{NH}$ may not be large enough to be discernible from natural variability, even by the end of the twentyfirst century (Fig. 5a). The role of aerosol forcing remains uncertain, but based on CMIP5 models, any influence from aerosol forcing is not discernible from natural variability.

4) The change in the phase of the PDO from positive to negative during the late 1990s contributed to tropical expansion over the last 30 years. However, even in model runs with prescribed SSTs, tropical widening rates vary substantially by up to $\sim 0.8^{\circ} \mathrm{decade}^{-1}$ (Figs. 1, 2), suggesting that internal atmospheric variability is needed to account for the exact rate of tropical widening observed in recent decades (e.g., Garfinkel et al. 2015).
Overall, we conclude that the observed tropical expansion in recent decades has been modest, is within the range of model simulations of the late twentieth and early twenty-first century, and occurred because of a combination of stratospheric ozone depletion, increasing GHGs, and natural variability (both coupled atmosphere-ocean variability and internal atmospheric variability).

The vast majority of observational records of the global atmospheric circulation only extend back to the beginning of the satellite era in the late 1970s, and we have observed an expansion of Earth's tropical belt since that time. However, the results above have demonstrated that attribution of atmospheric circulation trends over $30-40$-yr intervals is a very challenging exercise, as natural variability can induce large trends over such periods (Fig. 2, right column). Whether or not the observed tropical expansion is forced in part, natural variability-both internal atmospheric variability and coupled atmosphere-ocean variability-has likely played a sizeable role in the recent trend.

When trying to discern definitive anthropogenic influence, it will be necessary to look on longer time scales, and as the global observational record extends in time, we will have more confidence whether or not a forced trend is emerging in observations. Rather than waiting until later in the twenty-first century, one solution might be to carefully examine historical sea level pressure observations, which extend back into the late nineteenth century, to better contextualize the recent observed trends. Unfortunately, two twentieth-century reanalyses [NOAA-CIRES 20CR and ECMWF twentieth-century reanalysis (ERA-20C)], which assimilate only surface observations, show substantially different time series of tropical width over the twentieth century (cf. Fig. 1a of Simpson 2018), making it difficult to establish a longterm historical baseline to compare with the recent trend. But, based on the evidence currently available and 
presented in this paper, it seems very likely that human activities (through increasing GHGs and stratospheric ozone depletion) have contributed to a poleward shift of the SH tropical edge over the twentieth century and that further increases of GHGs would continue to force sizeable tropical expansion in the $\mathrm{SH}$ throughout the twentyfirst century.

Acknowledgments. We thank Ori Adam, Nick Davis, Isaac Held, Tim Merlis, Lorenzo Polvani, and one anonymous reviewer for helpful comments and suggestions. We thank U.S. CLIVAR and the International Space Science Institute (ISSI) for funding working groups that stimulated this project. We thank all members of the working groups for helpful discussions, and the U.S. CLIVAR and ISSI offices and their sponsoring agencies (NASA, NOAA, NSF, DOE, ESA, Swiss Confederation, Swiss Academy of Sciences, and University of Bern) for supporting these groups and activities. We acknowledge WCRP's Working Group on Coupled Modelling, which is responsible for CMIP, and we thank the climate modeling groups (Table 2) for producing and making available their model output. For CMIP, the U.S. DOE PCMDI provides coordinating support and led development of software infrastructure in partnership with the Global Organization for Earth System Science Portals.

\section{APPENDIX}

\section{Physical Relationship between the PSI500 and USFC Metrics}

Davis and Birner (2017) discuss the physical rationale for the close correspondence between the PSI500 and USFC metrics based on the vertically integrated zonalmean zonal momentum balance, and in this appendix, we present a slightly modified form of their argument, which focuses on the lower-tropospheric portion of the momentum balance. In the steady state, the lower branch of the Hadley circulation is in approximate Ekman balance between the Coriolis force acting on the lower-tropospheric equatorward flow and boundary layer $\mathrm{drag}^{\mathrm{A} 1}$ acting on the easterly zonal flow in the lower troposphere:

$$
-f[v] \approx-\frac{[u]}{\tau},
$$

where $f$ is the Coriolis parameter, $[u]$ is the zonal-mean zonal wind, $[v]$ is the zonal-mean meridional wind, and

\footnotetext{
${ }^{\text {A1 }}$ Here, the boundary layer drag is approximated as a linear relaxation with time-scale $\tau$.
}

$\tau$ is the frictional drag time scale. Integrating Eq. (A1) from the surface to $500 \mathrm{hPa}$ and assuming that the drag on $[u]$ due to boundary layer turbulence is negligible at $500 \mathrm{hPa}$, then

$$
f \Psi_{500} \propto-\frac{\left[u_{\text {sfc }}\right]}{\tau},
$$

where $\Psi_{500}$ is the zonal-mean meridional mass streamfunction at $500 \mathrm{hPa}$ and $\left[u_{\mathrm{sfc}}\right]$ is the near-surface zonalmean zonal wind.

Equation (A2) suggests that, if the Ekman balance shown in Eq. (A1) dominates between the surface and $500 \mathrm{hPa}$, we would expect the zero-crossing latitudes of the $\Psi_{500}$ and $\left[u_{\mathrm{sfc}}\right]$ fields (i.e., the PSI500 and USFC metrics) to be the same. In reality, the mean location of the USFC metric is slightly poleward of that of the PSI500 metric in both observations and models, as the descending branch of the Hadley circulation slants poleward in the lower troposphere in both hemispheres (cf. Fig. 2 of Davis and Birner 2017). Thus, other terms in the zonal-mean zonal momentum balance are not entirely negligible between the surface and $500 \mathrm{hPa}$. Ultimately, the location of the USFC metric is determined by the vertically integrated momentum forcing between the surface and the top of the atmosphere. This momentum forcing is concentrated in the upper troposphere, where it also acts as a dominant forcing of the streamfunction field and hence the PSI500 metric. The dominant portion of the momentum forcing is due to eddies, with a secondary contribution due to zonal mean advection.

\section{REFERENCES}

Adam, O., T. Schneider, and N. Harnik, 2014: Role of changes in mean temperatures versus temperature gradients in the recent widening of the Hadley circulation. J. Climate, 27, 7450-7461, https://doi.org/10.1175/JCLI-D-14-00140.1.

, and Coauthors, 2018a: TropD: Tropical width diagnostics software package, version 1.0. Zenodo, https://doi.org/10.5281/ zenodo.1157043.

, and Coauthors, 2018b: The TropD software package (v1): Standardized methods for calculating tropical-width diagnostics. Geosci. Model Dev., 11, 4339-4357, https://doi.org/ 10.5194/gmd-11-4339-2018.

Allen, R. J., and S. C. Sherwood, 2011: The impact of natural versus anthropogenic aerosols on atmospheric circulation in the Community Atmosphere Model. Climate Dyn., 36, 1959-1978, https://doi.org/10.1007/s00382-010-0898-8.

, and O. Ajoku, 2016: Future aerosol reductions and widening of the northern tropical belt. J. Geophys. Res. Atmos., 121, 6765-6786, https://doi.org/10.1002/2016JD024803.

, and M. Kovilakam, 2017: The role of natural climate variability in recent tropical expansion. J. Climate, 30, 6329-6350, https://doi.org/10.1175/JCLI-D-16-0735.1.

_ S. C. Sherwood, J. R. Norris, and C. S. Zender, 2012a: The equilibrium response to idealized thermal forcings in a comprehensive GCM: Implications for recent tropical expansion. 
Atmos. Chem. Phys., 12, 4795-4816, https://doi.org/10.5194/ acp-12-4795-2012.

, — $-\longrightarrow$, and —, 2012b: Recent Northern Hemisphere tropical expansion primarily driven by black carbon and tropospheric ozone. Nature, 485, 350-354, https://doi.org/10.1038/ nature11097.

_ J. R. Norris, and M. Kovilakam, 2014: Influence of anthropogenic aerosols and the Pacific decadal oscillation on tropical belt width. Nat. Geosci., 7, 270-274, https://doi.org/10.1038/ngeo2091.

Amaya, D. J., N. Siler, S. Xie, and A. J. Miller, 2018: The interplay of internal and forced modes of Hadley cell expansion: Lessons from the global warming hiatus. Climate Dyn., 51, 305-319, https://doi.org/10.1007/s00382-017-3921-5.

Archer, C. L., and K. Caldeira, 2008: Historical trends in the jet streams. Geophys. Res. Lett., 35, L08803, https://doi.org/ 10.1029/2008GL033614.

Bamston, A. G., M. Chelliah, and S. B. Goldenberg, 1997: Documentation of a highly ENSO-related SST region in the equatorial Pacific: Research note. Atmos.-Ocean, 35, 367383, https://doi.org/10.1080/07055900.1997.9649597.

Barnes, E. A., and L. M. Polvani, 2015: CMIP5 projections of Arctic amplification, of the North American/North Atlantic circulation, and of their relationship. J. Climate, 28, 5254-5271, https://doi.org/10.1175/JCLI-D-14-00589.1.

— N. W. Barnes, and L. M. Polvani, 2014: Delayed Southern Hemisphere climate change induced by stratospheric ozone recovery, as projected by the CMIP5 models. J. Climate, 27, 852-867, https://doi.org/10.1175/JCLI-D-13-00246.1.

Birner, T., S. M. Davis, and D. J. Seidel, 2014: The changing width of Earth's tropical belt. Phys. Today, 67,38-44, https://doi.org/ 10.1063/PT.3.2620.

Bond, T. C., and Coauthors, 2013: Bounding the role of black carbon in the climate system: A scientific assessment. J. Geophys. Res. Atmos., 118, 5380-5552, https://doi.org/ 10.1002/jgrd.50171.

Brayshaw, D. J., B. Hoskins, and M. Blackburn, 2008: The stormtrack response to idealized SST perturbations in an aquaplanet GCM. J. Atmos. Sci., 65, 2842-2860, https://doi.org/ 10.1175/2008JAS2657.1.

Bretherton, C. S., and D. S. Battisti, 2000: An interpretation of the results from atmospheric general circulation models forced by the time history of the observed sea surface temperature distribution. Geophys. Res. Lett., 27, 767-770, https://doi.org/ 10.1029/1999GL010910.

Brönnimann, S., A. M. Fischer, E. Rozanov, P. Poli, G. P. Compo, and P. D. Sardeshmukh, 2015: Southward shift of the northern tropical belt from 1945 to 1980. Nat. Geosci., 8, 969-974, https://doi.org/10.1038/ngeo2568.

Butler, A. H., D. W. J. Thompson, and R. Heikes, 2010: The steadystate atmospheric circulation response to climate change-like thermal forcings in a simple general circulation model. $J$. Climate, 23, 3474-3496, https://doi.org/10.1175/2010JCLI3228.1.

,-- , and T. Birner, 2011: Isentropic slopes, downgradient eddy fluxes, and the extratropical atmospheric circulation response to tropical tropospheric heating. J. Atmos. Sci., 68 , 2292-2305, https://doi.org/10.1175/JAS-D-10-05025.1.

Cane, M. A., A. C. Clement, A. Kaplan, Y. Kushnir, D. Pozdnyakov, R. Seager, S. E. Zebiak, and R. Murtugudde, 1997: Twentiethcentury sea surface temperature trends. Science, 275, 957-960, https://doi.org/10.1126/science.275.5302.957.

Carpenter, L. J., and Coauthors, 2014: Ozone-depleting substances (ODSs) and other gases of interest to the Montreal Protocol. Scientific assessment of ozone depletion: 2014,
World Meteorological Organization Global Ozone Research and Monitoring Project Rep. 55, 1-101.

Ceppi, P., and D. L. Hartmann, 2016: Clouds and the atmospheric circulation response to warming. J. Climate, 29, 783-799, https://doi.org/10.1175/JCLI-D-15-0394.1.

Choi, J., S.-W. Son, and R. J. Park, 2019: Aerosol versus greenhouse gas impacts on Southern Hemisphere general circulation changes. Climate Dyn., https://doi.org/10.1007/ s00382-018-4370-5, in press.

Coats, S., and K. B. Karnauskas, 2017: Are simulated and observed 20th century tropical Pacific sea surface temperature trends significant relative to internal variability? Geophys. Res. Lett., 44, 9928-9937, https://doi.org/10.1002/2017GL074622.

Davis, N. A., and T. Birner, 2013: Seasonal to multidecadal variability of the width of the tropical belt. J. Geophys. Res., 118, 7773-7787, https://doi.org/10.1002/jgrd.50610.

$\longrightarrow$, and - 2017: On the discrepancies in tropical belt expansion between reanalyses and climate models and among tropical belt width metrics. J. Climate, 30, 1211-1231, https:// doi.org/10.1175/JCLI-D-16-0371.1.

— trend estimates in reanalyses. Geophys. Res. Lett., 45, 11439 11 446, https://doi.org/10.1029/2018GL079593.

—- D. J. Seidel, T. Birner, S. M. Davis, and S. Tilmes, 2016: Changes in the width of the tropical belt due to simple radiative forcing changes in the GeoMIP simulations. Atmos. Chem. Phys., 16, $10083-10095$, https://doi.org/10.5194/ acp-16-10083-2016.

Davis, S. M., and K. H. Rosenlof, 2012: A multidiagnostic intercomparison of tropical-width time series using reanalyses and satellite observations. J. Climate, 25, 1061-1078, https:// doi.org/10.1175/JCLI-D-11-00127.1.

Dee, D. P., and Coauthors, 2011: The ERA-Interim reanalysis: Configuration and performance of the data assimilation system. Quart. J. Roy. Meteor. Soc., 137, 553-597, https://doi.org/ 10.1002/qj.828.

Deser, C., R. A. Tomas, and L. Sun, 2015: The role of oceanatmosphere coupling in the zonal-mean atmospheric response to Arctic sea ice loss. J. Climate, 28, 2168-2186, https://doi.org/ 10.1175/JCLI-D-14-00325.1.

ECMWF, 2004: ERA-40, monthly means of daily means. ECMWF, accessed 5 February 2018, http://apps.ecmwf.int/datasets/data/ era40-moda.

_ 2009: ERA-Interim, monthly means of daily means. ECMWF, accessed 13 February 2017, http://apps.ecmwf.int/ datasets/data/interim-full-moda.

Eyring, V., and Coauthors, 2013: Long-term ozone changes and associated climate impacts in CMIP5 simulations. J. Geophys Res. Atmos., 118, 5029-5060, https://doi.org/10.1002/jgrd.50316.

Frierson, D. M. W., J. Lu, and G. Chen, 2007: Width of the Hadley cell in simple and comprehensive general circulation models. Geophys. Res. Lett., 34, L18804, https://doi.org/ 10.1029/2007GL031115.

Fu, Q., and P. Lin, 2011: Poleward shift of subtropical jets inferred from satellite-observed lower-stratospheric temperatures. J. Climate, 24, 5597-5603, https://doi.org/10.1175/ JCLI-D-11-00027.1.

— C. M. Johanson, J. M. Wallace, and T. Reichler, 2006: Enhanced mid-latitude tropospheric warming in satellite measurements. Science, 312, 1179-1179, https://doi.org/10.1126/ science. 1125566

Fujiwara, M., and Coauthors, 2017: Introduction to the SPARC Reanalysis Intercomparison Project (S-RIP) and overview of 
the reanalysis systems. Atmos. Chem. Phys., 17, 1417-1452, https://doi.org/10.5194/acp-17-1417-2017.

Garfinkel, C. I., D. W. Waugh, and L. M. Polvani, 2015: Recent Hadley cell expansion: The role of internal atmospheric variability in reconciling modeled and observed trends. Geophys. Res. Lett., $\mathbf{4 2}$, 10 824-10 831, https://doi.org/10.1002/2015GL066942.

Gelaro, R., and Coauthors, 2017: The Modern-Era Retrospective Analysis for Research and Applications, version 2 (MERRA-2). J. Climate, 30, 5419-5454, https://doi.org/10.1175/JCLID-16-0758.1.

Gillett, N. P., and D. W. J. Thompson, 2003: Simulation of recent Southern Hemisphere climate change. Science, 302, 273-275, https://doi.org/10.1126/science.1087440.

Grassi, B., G. Redaelli, P. O. Canziani, and G. Visconti, 2012: Effects of the PDO phase on the tropical belt width. J. Climate, 25, 3282-3290, https://doi.org/10.1175/JCLI-D-11-00244.1.

Grise, K. M., and L. M. Polvani, 2014: The response of midlatitude jets to increased $\mathrm{CO}_{2}$ : Distinguishing the roles of sea surface temperature and direct radiative forcing. Geophys. Res. Lett., 41, 6863-6871, https://doi.org/10.1002/2014GL061638.

$\longrightarrow$, and - 2016: Is climate sensitivity related to dynamical sensitivity? J. Geophys. Res. Atmos., 121, 5159-5176, https:// doi.org/10.1002/2015JD024687.

— S. M. Davis, P. W. Staten, and O. Adam, 2018: Regional and seasonal characteristics of the recent expansion of the tropics. J. Climate, 31, 6839-6856, https://doi.org/10.1175/JCLI-D-18-0060.1.

Guo, Y.-P., and J.-P. Li, 2016: Impact of ENSO events on the interannual variability of Hadley circulation extents in boreal winter. Adv. Climate Change Res., 7, 46-53, https:// doi.org/10.1016/j.accre.2016.05.001.

Harvey, B. J., L. C. Shaffrey, and T. J. Woollings, 2015: Deconstructing the climate change response of the Northern Hemisphere wintertime storm tracks. Climate Dyn., 45, 28472860, https://doi.org/10.1007/s00382-015-2510-8.

Hawkins, E., and R. Sutton, 2012: Time of emergence of climate signals. Geophys. Res. Lett., 39, L01702, https://doi.org/10.1029/ 2011 GL050087.

He, J., and B. J. Soden, 2015: Anthropogenic weakening of the tropical circulation: The relative roles of direct $\mathrm{CO}_{2}$ forcing and sea surface temperature change. J. Climate, 28, 8728-8742, https://doi.org/10.1175/JCLI-D-15-0205.1.

— tropical precipitation decline. Nat. Climate Change, 7, 53-57, https://doi.org/10.1038/nclimate3157.

$\mathrm{Hu}$, Y., and Q. Fu, 2007: Observed poleward expansion of the Hadley circulation since 1979. Atmos. Chem. Phys., 7, 52295236, https://doi.org/10.5194/acp-7-5229-2007.

— L L. Tao, and J. Liu, 2013: Poleward expansion of the Hadley circulation in CMIP5 simulations. Adv. Atmos. Sci., 30, 790 795, https://doi.org/10.1007/s00376-012-2187-4.

Hudson, R. D., M. F. Andrade, M. B. Follette, and A. D. Frolov, 2006: The total ozone field separated into meteorological regimes-Part II: Northern Hemisphere mid-latitude total ozone trends. Atmos. Chem. Phys., 6, 5183-5191, https:// doi.org/10.5194/acp-6-5183-2006.

JMA, 2013: JRA-55: Japanese 55-year Reanalysis, monthly means and variances. National Center for Atmospheric Research Computational and Information Systems Laboratory Research Data Archive, accessed 13 February 2017, https:// doi.org/10.5065/D60G3H5B.

Johanson, C. M., and Q. Fu, 2009: Hadley cell widening: Model simulations versus observations. J. Climate, 22, 2713-2725, https://doi.org/10.1175/2008JCLI2620.1.
Kalnay, E., and Coauthors, 1996: The NCEP/NCAR 40-Year Reanalysis Project. Bull. Amer. Meteor. Soc., 77, 437-471, https:// doi.org/10.1175/1520-0477(1996)077<0437:TNYRP>2.0.CO;2.

Kanamitsu, M., W. Ebisuzaki, J. Woollen, S. Yang, J. J. Hnilo, M. Fiorino, and G. L. Potter, 2002: NCEP-DOE AMIP-II Reanalysis (R-2). Bull. Amer. Meteor. Soc., 83, 1631-1643, https://doi.org/10.1175/BAMS-83-11-1631.

Kang, S. M., C. Deser, and L. M. Polvani, 2013: Uncertainty in climate change projections of the Hadley circulation: The role of internal variability. J. Climate, 26, 7541-7554, https:// doi.org/10.1175/JCLI-D-12-00788.1.

Karnauskas, K. B., R. Seager, A. Kaplan, Y. Kushnir, and M. A. Cane, 2009: Observed strengthening of the zonal sea surface temperature gradient across the equatorial Pacific Ocean. J. Climate, 22, 4316-4321, https://doi.org/10.1175/2009JCLI2936.1.

Kay, J. E., and Coauthors, 2015: The Community Earth System Model (CESM) Large Ensemble project: A community resource for studying climate change in the presence of internal climate variability. Bull. Amer. Meteor. Soc., 96, 1333-1349, https://doi.org/10.1175/BAMS-D-13-00255.1.

Keeling, C. D., S. C. Piper, R. B. Bacastow, M. Wahlen, T. P. Whorf, M. Heimann, and H. A. Meijer, 2001: Exchanges of atmospheric $\mathrm{CO}_{2}$ and ${ }^{13} \mathrm{CO}_{2}$ with the terrestrial biosphere and oceans from 1978 to 2000. I. Global aspects. Scripps Institution of Oceanography Reference 01-06, 88 pages.

Kistler, R., and Coauthors, 2001: The NCEP-NCAR 50-Year Reanalysis: Monthly means CD-ROM and documentation. Bull. Amer. Meteor. Soc., 82, 247-267, https://doi.org/10.1175/ 1520-0477(2001)082<0247:TNNYRM >2.3.CO;2.

Kobayashi, S., and Coauthors, 2015: The JRA-55 Reanalysis: General specifications and basic characteristics. J. Meteor. Soc. Japan, 93, 5-48, https://doi.org/10.2151/jmsj.2015-001.

Korty, R. L., and T. Schneider, 2008: Extent of Hadley circulations in dry atmospheres. Geophys. Res. Lett., 35, L23803, https:// doi.org/10.1029/2008GL035847.

Kosaka, Y., and S.-P. Xie, 2013: Recent global-warming hiatus tied to equatorial Pacific surface cooling. Nature, 501, 403-407, https://doi.org/10.1038/nature12534.

— and - 2016: The tropical Pacific as a key pacemaker of the variable rates of global warming. Nat. Geosci., 9, 669-673, https://doi.org/10.1038/ngeo2770.

Kovilakam, M., and S. Mahajan, 2015: Black carbon aerosol-induced Northern Hemisphere tropical expansion. Geophys. Res. Lett., 42, 4964-4972, https://doi.org/10.1002/2015GL064559.

Long, C. S., M. Fujiwara, S. Davis, D. M. Mitchell, and C. J. Wright, 2017: Climatology and interannual variability of dynamic variables in multiple reanalyses evaluated by the SPARC Reanalysis Intercomparison Project (S-RIP). Atmos. Chem. Phys., 17, 14 593-14 629, https://doi.org/10.5194/acp-17-14593-2017.

Lu, J., G. A. Vecchi, and T. Reichler, 2007: Expansion of the Hadley cell under global warming. Geophys. Res. Lett., 34, L06805, https://doi.org/10.1029/2006GL028443.

, G. Chen, and D. M. W. Frierson, 2008: Response of the zonal mean atmospheric circulation to El Niño versus global warming. J. Climate, 21, 5835-5851, https://doi.org/10.1175/ 2008JCLI2200.1.

, C. Deser, and T. Reichler, 2009: Cause of the widening of the tropical belt since 1958. Geophys. Res. Lett., 36, L03803, https://doi.org/10.1029/2008GL036076.

, G. Chen, and D. M. W. Frierson, 2010: The position of the midlatitude storm track and eddy-driven westerlies in aquaplanet ACGMS. J. Atmos. Sci., 67, 3984-4000, https://doi.org/ 10.1175/2010JAS3477.1. 
Lucas, C., B. Timbal, and H. Nguyen, 2014: The expanding tropics: A critical assessment of the observational and modeling studies. Wiley Interdiscip. Rev.: Climate Change, $\mathbf{5}$, 89-112, https://doi.org/10.1002/wcc.251.

Mantsis, D. F., S. Sherwood, R. Allen, and L. Shi, 2017: Natural variations of tropical width and recent trends. Geophys. Res. Lett., 44, 3825-3832, https://doi.org/10.1002/2016GL072097.

Marsh, D. R., M. J. Mills, D. E. Kinnison, J. Lamarque, N. Calvo, and L. M. Polvani, 2013: Climate change from 1850 to 2005 simulated in CESM1(WACCM). J. Climate, 26, 7372-7391, https://doi.org/10.1175/JCLI-D-12-00558.1.

McLandress, C., T. G. Shepherd, J. F. Scinocca, D. A. Plummer, M. Sigmond, A. I. Jonsson, and M. C. Reader, 2011: Separating the dynamical effects of climate change and ozone depletion. Part II: Southern Hemisphere troposphere. J. Climate, 24, 1850-1868, https://doi.org/10.1175/2010JCLI3958.1.

Met Office Hadley Centre, 2000: Hadley Centre Global Sea Ice and Sea Surface Temperature (HadISST), version 1.1. Met Office Hadley Centre, accessed 19 September 2017, https:// www.metoffice.gov.uk/hadobs/hadisst.

Min, S.-K., and S.-W. Son, 2013: Multimodel attribution of the Southern Hemisphere Hadley cell widening: Major role of ozone depletion. J. Geophys. Res. Atmos., 118, 3007-3015, https://doi.org/10.1002/jgrd.50232.

Ming, Y., V. Ramaswamy, and G. Chen, 2011: A model investigation of aerosol-induced changes in boreal winter extratropical circulation. J. Climate, 24, 6077-6091, https:// doi.org/10.1175/2011JCLI4111.1.

NASA GMAO, 2015a: M2TMNXSLV: MERRA-2 tavgM_2d_slv_ $\mathrm{Nx}$ : 2d, monthly mean, time-averaged, single-level, assimilation, single-level diagnostics, version 5.12.4. Goddard Earth Sciences Data and Information Services Center, accessed 13 February 2017, https://doi.org/10.5067/AP1B0BA5PD2K.

——, 2015b: M2IMNPASM: MERRA-2 instM_3d_asm_Np: 3d, monthly mean, instantaneous, pressure-level, assimilation, assimilated meteorological fields, version 5.12.4. Goddard Earth Sciences Data and Information Services Center, accessed 13 February 2017, https://doi.org/ 10.5067/2E096JV59PK7.

NCAR, 2014: LENS: Data sets available to the community. NCAR, accessed 29 June 2017, http://www.cesm.ucar.edu/ projects/community-projects/LENS/data-sets.html.

NCEP, 1994: NCEP/NCAR Reanalysis 1. NOAA/Earth System Research Laboratory/Physical Sciences Division, accessed 5 February 2018, https://www.esrl.noaa.gov/psd/data/gridded/ data.ncep.reanalysis.html.

__, 2002: NCEP-DOE AMIP-II Reanalysis. NOAA/Earth System Research Laboratory/Physical Sciences Division, accessed 17 April 2017, https://www.esrl.noaa.gov/psd/data/ gridded/data.ncep.reanalysis2.html.

Newman, M., and Coauthors, 2016: The Pacific decadal oscillation, revisited. J. Climate, 29, 4399-4427, https://doi.org/10.1175/ JCLI-D-15-0508.1.

Nguyen, H., A. Evans, C. Lucas, I. Smith, and B. Timbal, 2013: The Hadley circulation in reanalyses: Climatology, variability, and change. J. Climate, 26, 3357-3376, https://doi.org/10.1175/ JCLI-D-12-00224.1.

— C. Lucas, A. Evans, B. Timbal, and L. Hanson, 2015: Expansion of the Southern Hemisphere Hadley cell in response to greenhouse gas forcing. J. Climate, 28, 8067-8077, https:// doi.org/10.1175/JCLI-D-15-0139.1.

Oort, A. H., and J. J. Yienger, 1996: Observed interannual variability in the Hadley circulation and its connection to
ENSO. J. Climate, 9, 2751-2767, https://doi.org/10.1175/ 1520-0442(1996)009<2751:OIVITH >2.0.CO;2.

Polvani, L. M., D. W. Waugh, G. J. P. Correa, and S. Son, 2011a: Stratospheric ozone depletion: The main driver of twentiethcentury atmospheric circulation changes in the Southern Hemisphere. J. Climate, 24, 795-812, https://doi.org/10.1175/ 2010JCLI3772.1.

_- M. Previdi, and C. Deser, 2011b: Large cancellation, due to ozone recovery, of future Southern Hemisphere atmospheric circulation trends. Geophys. Res. Lett., 38, L04707, https:// doi.org/10.1029/2011GL046712.

Quaas, J., and Coauthors, 2009: Aerosol indirect effects-General circulation model intercomparison and evaluation with satellite data. Atmos. Chem. Phys., 9, 8697-8717, https://doi.org/ 10.5194/acp-9-8697-2009.

Quan, X.-W., M. P. Hoerling, J. Perlwitz, H. F. Diaz, and T. Xu, 2014: How fast are the tropics expanding? J. Climate, 27, 1999-2013, https://doi.org/10.1175/JCLI-D-13-00287.1.

$-\ldots, \ldots, \ldots$, and ——, 2018: On the time of emergence of tropical width change. J. Climate, 31, 7225-7236, https:// doi.org/10.1175/JCLI-D-18-0068.1.

Randel, W. J., and F. Wu, 1999: Cooling of the Arctic and Antarctic polar stratospheres due to ozone depletion. J. Climate, $\mathbf{1 2}$ 1467-1479, https://doi.org/10.1175/1520-0442(1999)012<1467: COTAAA $>2.0 . \mathrm{CO} ; 2$.

Rayner, N. A., D. E. Parker, E. B. Horton, C. K. Folland, L. V. Alexander, D. P. Rowell, E. C. Kent, and A. Kaplan, 2003: Global analyses of sea surface temperature, sea ice, and night marine air temperature since the late nineteenth century. J. Geophys. Res., 108, 4407, https://doi.org/10.1029/ 2002JD002670.

Saha, S., and Coauthors, 2010a: NCEP Climate Forecast System Reanalysis (CFSR) monthly products, January 1979 to December 2010. National Center for Atmospheric Research Computational and Information Systems Laboratory Research Data Archive, accessed 21 April 2017, https://doi.org/ 10.5065/D6DN438J.

- and Coauthors, 2010b: The NCEP Climate Forecast System Reanalysis. Bull. Amer. Meteor. Soc., 91, 1015-1058, https:// doi.org/10.1175/2010BAMS3001.1.

— , and Coauthors, 2012: NCEP Climate Forecast System version 2 (CFSv2) monthly products. National Center for Atmospheric Research Computational and Information Systems Laboratory Research Data Archive, accessed 11 June 2018, https://doi.org/10.5065/D69021ZF.

— version 2. J. Climate, 27, 2185-2208, https://doi.org/10.1175/ JCLI-D-12-00823.1.

Santer, B. D., T. M. L. Wigley, J. S. Boyle, D. J. Gaffen, J. J. Hnilo, D. Nychka, D. E. Parker, and K. E. Taylor, 2000: Statistical significance of trends and trend differences in layer-average atmospheric temperature time series. J. Geophys. Res., $\mathbf{1 0 5}$ 7337-7356, https://doi.org/10.1029/1999JD901105.

Seager, R., N. Harnik, Y. Kushnir, W. Robinson, and J. Miller, 2003: Mechanisms of hemispherically symmetric climate variability. J. Climate, 16, 2960-2978, https://doi.org/10.1175/ 1520-0442(2003)016<2960:MOHSCV > 2.0.CO;2.

Seidel, D. J., and W. J. Randel, 2007: Recent widening of the tropical belt: Evidence from tropopause observations. J. Geophys. Res., 112, D20113, https://doi.org/10.1029/2007JD008861.

- Q. Fu, W. J. Randel, and T. J. Reichler, 2008: Widening of the tropical belt in a changing climate. Nat. Geosci., 1, 21-24, https://doi.org/10.1038/ngeo.2007.38. 
Shaw, T. A., and Coauthors, 2016: Storm track processes and the opposing influences of climate change. Nat. Geosci., 9, 656664, https://doi.org/10.1038/ngeo2783.

Shen, Z., and Y. Ming, 2018: The influence of aerosol absorption on the extratropical circulation. J. Climate, 31, 5961-5975, https:// doi.org/10.1175/JCLI-D-17-0839.1.

Simpson, I., 2018: Natural variability in the width of the tropics. US CLIVAR Variations, Vol. 16, No. 2, U.S. CLIVAR Project Office, Washington, DC, 14-20.

— T. Shaw, and R. Seager, 2014: A diagnosis of the seasonally and longitudinally varying midlatitude circulation response to global warming. J. Atmos. Sci., 71, 2489-2515, https://doi.org/ 10.1175/JAS-D-13-0325.1.

Smith, D. M., and Coauthors, 2016: Role of volcanic and anthropogenic aerosols in the recent global surface warming slowdown. Nat. Climate Change, 6, 936-940, https://doi.org/ 10.1038/nclimate3058.

Solomon, A., and L. M. Polvani, 2016: Highly significant responses to anthropogenic forcings of the midlatitude jet in the Southern Hemisphere. J. Climate, 29, 3463-3460, https:// doi.org/10.1175/JCLI-D-16-0034.1.

— - _ D. W. Waugh, and S. M. Davis, 2016: Contrasting upper and lower atmospheric metrics of tropical expansion in the Southern Hemisphere. Geophys. Res. Lett., 43, 10 496-10 503, https://doi.org/10.1002/2016GL070917.

Solomon, S., D. J. Ivy, D. Kinnison, M. J. Mills, R. R. Neely, and A. Schmidt, 2016: Emergence of healing in the Antarctic ozone layer. Science, 353, 269-274, https://doi.org/10.1126/ science.aae 0061 .

_- , and Coauthors, 2017: Mirrored changes in Antarctic ozone and stratospheric temperature in the late 20th versus early 21st centuries. J. Geophys. Res. Atmos., 122, 8940-8950, https://doi.org/10.1002/2017JD026719.

Son, S.-W., N. F. Tandon, L. M. Polvani, and D. W. Waugh, 2009: Ozone hole and Southern Hemisphere climate change. Geophys. Res. Lett., 36, L15705, https://doi.org/10.1029/2009GL038671.

_ , and Coauthors, 2010: Impact of stratospheric ozone on Southern Hemisphere circulation change: A multimodel assessment. J. Geophys. Res., 115, D00M07, https://doi.org/ 10.1029/2010JD014271.

Stachnik, J. P., and C. Schumacher, 2011: A comparison of the Hadley circulation in modern reanalyses. J. Geophys. Res., 116, D22102, https://doi.org/10.1029/2011JD016677.

Staten, P. W., J. J. Rutz, T. Reichler, and J. Lu, 2012: Breaking down the tropospheric circulation response by forcing. Climate Dyn., 39, 2361-2375, https://doi.org/10.1007/s00382-011-1267-y.

—_, J. Lu, K. M. Grise, S. M. Davis, and T. Birner, 2018: Reexamining tropical expansion. Nat. Climate Change, 8, 768 775, https://doi.org/10.1038/s41558-018-0246-2.

Steptoe, H., L. J. Wilcox, and E. J. Highwood, 2016: Is there a robust effect of anthropogenic aerosols on the southern annular mode? J. Geophys. Res. Atmos., 121, $10029-10042$, https://doi.org/10.1002/2015JD024218.

Sun, Y., L. Z. X. Li, G. Ramstein, T. Zhou, N. Tan, M. Kageyama, and S. Wang, 2019: Regional meridional cells governing the interannual variability of the Hadley circulation in boreal winter. Climate Dyn., https://doi.org/ 10.1007/s00382-018-4263-7, in press.

Tandon, N. F., and M. A. Cane, 2017: Which way will the circulation shift in a changing climate? Possibility nonlinearity of extratropical cloud feedbacks. Climate Dyn., 48, 3759-3777, https://doi.org/10.1007/s00382-016-3301-6.
— E. Gerber, A. Sobel, and L. Polvani, 2013: Understanding Hadley cell expansion versus contraction: Insights from simplified models and implications for recent observations. J. Climate, 26, 4304-4321, https://doi.org/10.1175/JCLID-12-00598.1.

Tans, P., 2018: Mauna Loa $\mathrm{CO}_{2}$ annual mean data. NOAA/Earth System Research Laboratory/Global Monitoring Division, accessed 5 June 2018, https://www.esrl.noaa.gov/gmd/ccgg/ trends/data.html.

Tao, L., Y. Hu, and J. Liu, 2016: Anthropogenic forcing on the Hadley circulation in CMIP5 simulations. Climate Dyn., 46, 3337-3350, https://doi.org/10.1007/s00382-015-2772-1.

Taylor, K. E., R. J. Stouffer, and G. A. Meehl, 2012: An overview of CMIP5 and the experiment design. Bull. Amer. Meteor. Soc., 93, 485-498, https://doi.org/10.1175/BAMS-D-11-00094.1.

Thomas, J. L., D. W. Waugh, and A. Gnanadesikan, 2015: Southern Hemisphere extratropical circulation: Recent trends and natural variability. Geophys. Res. Lett., 42, 55085515, https://doi.org/10.1002/2015GL064521.

Thompson, D. W. J., and S. Solomon, 2002: Interpretation of recent Southern Hemisphere climate change. Science, 296, 895-899, https://doi.org/10.1126/science.1069270.

$\longrightarrow,-$ P. J. Kushner, M. H. England, K. M. Grise, and D. J. Karoly, 2011: Signatures of the Antarctic ozone hole in Southern Hemisphere surface climate change. Nat. Geosci., 4, 741-749, https://doi.org/10.1038/ngeo1296.

Trenberth, K., 1997: The definition of El Niño. Bull. Amer. Meteor. Soc., 78, 2771-2777, https://doi.org/10.1175/ 1520-0477(1997)078<2771:TDOENO > 2.0.CO;2.

Uppala, S. M., and Coauthors, 2005: The ERA-40 Reanalysis. Quart. J. Roy. Meteor. Soc., 131, 2961-3012, https://doi.org/ 10.1256/qj.04.176.

Vallis, G. K., P. Zurita-Gotor, C. Cairns, and J. Kidston, 2015: Response of the large-scale structure of the atmosphere to global warming. Quart. J. Roy. Meteor. Soc., 141, 1479-1501, https://doi.org/10.1002/qj.2456.

Voigt, A., and T. A. Shaw, 2015: Circulation response to warming shaped by radiative changes of clouds and water vapor. Nat. Geosci., 8, 102-106, https://doi.org/10.1038/ngeo2345.

Waugh, D. W., W. J. Randel, S. Pawson, P. A. Newman, and E. R. Nash, 1999: Persistence of the lower stratospheric polar vortices. J. Geophys. Res., 104, 27 191-27 201, https://doi.org/ 10.1029/1999JD900795.

, C. I. Garfinkel, and L. M. Polvani, 2015: Drivers of the recent tropical expansion in the Southern Hemisphere: Changing SSTs or ozone depletion? J. Climate, 28, 6581-6586, https:// doi.org/10.1175/JCLI-D-15-0138.1.

- and Coauthors, 2018: Revisiting the relationship among metrics of tropical expansion. J. Climate, 31, 7565-7581, https://doi.org/10.1175/JCLI-D-18-0108.1.

WCRP, 2011: Coupled Model Intercomparison Project, phase 5. Lawrence Livermore National Laboratory, accessed 7 March 2018, https://esgf-node.llnl.gov/search/cmip5/.

Wu, R., and B. P. Kirtman, 2005: Roles of Indian and Pacific Ocean air-sea coupling in tropical atmospheric variability. Climate Dyn., 25, 155-170, https://doi.org/10.1007/ s00382-005-0003-x.

Young, P. J., and Coauthors, 2018: Tropospheric ozone assessment report: Assessment of global-scale model performance for global and regional ozone distributions, variability, and trends. Elementa, 6, 10, https://doi.org/ 10.1525/elementa.265. 